\title{
Behavioural indicators of welfare in farmed fish
}

\author{
Catarina I. M. Martins $\cdot$ Leonor Galhardo $\cdot$ Chris Noble $\cdot$ Børge Damsgård • \\ Maria T. Spedicato · Walter Zupa • Marilyn Beauchaud • Ewa Kulczykowska • \\ Jean-Charles Massabuau • Toby Carter · Sònia Rey Planellas · Tore Kristiansen
}

Received: 21 October 2010/ Accepted: 20 May 2011/Published online: 28 July 2011

(C) The Author(s) 2011. This article is published with open access at Springerlink.com

\begin{abstract}
Behaviour represents a reaction to the environment as fish perceive it and is therefore a key element of fish welfare. This review summarises the main findings on how behavioural changes have been used to assess welfare in farmed fish, using both functional and feeling-based approaches. Changes in foraging behaviour, ventilatory activity, aggression,
\end{abstract}

C. I. M. Martins ( $\square)$

Centro de Ciências do Mar do Algarve (CCMAR),

Universidade do Algarve, Campus de Gambelas,

8005-139 Faro, Portugal

e-mail: cimartins@ualg.pt

\section{I. M. Martins}

Aquaculture and Fisheries Group, Wageningen

University, P.O. Box 338, 6700 AH Wageningen,

The Netherlands

L. Galhardo

Instituto Superior de Psicologia Aplicada, Unidade de Investigação em Eco-Etologia, Rua Jardim do Tabaco 34, 1149-041 Lisbon, Portugal

C. Noble · B. Damsgård

Nofima Marin, P.O. Box 6122, 9291 Tromsö, Norway

M. T. Spedicato · W. Zupa

COISPA Tecnologia \& Ricerca, via dei Trulli,

18-20, 70126 Bari, Italy

M. Beauchaud

Laboratoire Ecologie et Neuro-Ethologie Sensorielles

(EA3988), Université Jean Monnet, 23 rue Dr Paul

Michelon, 42023 Saint-Etienne Cedex 02, France individual and group swimming behaviour, stereotypic and abnormal behaviour have been linked with acute and chronic stressors in aquaculture and can therefore be regarded as likely indicators of poor welfare. On the contrary, measurements of exploratory behaviour, feed anticipatory activity and rewardrelated operant behaviour are beginning to be considered as indicators of positive emotions and welfare in

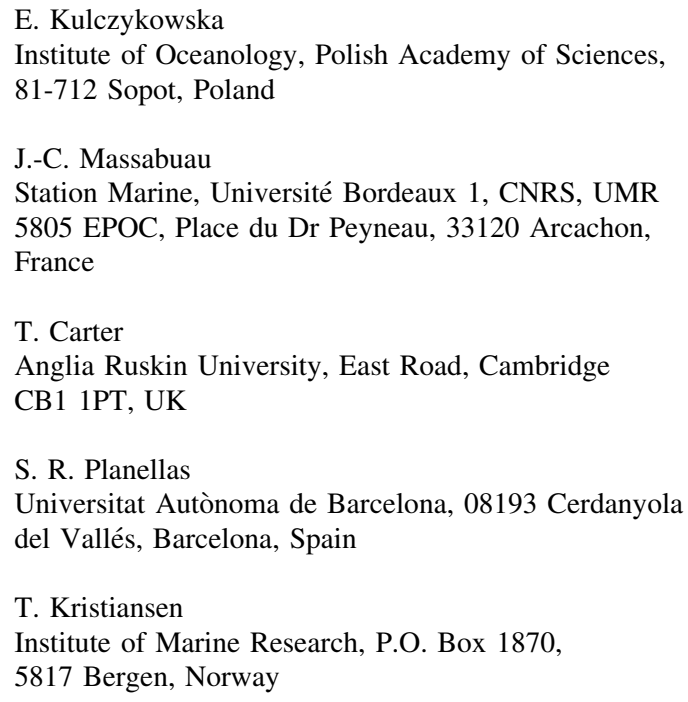


fish. Despite the lack of scientific agreement about the existence of sentience in fish, the possibility that they are capable of both positive and negative emotions may contribute to the development of new strategies (e.g. environmental enrichment) to promote good welfare. Numerous studies that use behavioural indicators of welfare show that behavioural changes can be interpreted as either good or poor welfare depending on the fish species. It is therefore essential to understand the species-specific biology before drawing any conclusions in relation to welfare. In addition, different individuals within the same species may exhibit divergent coping strategies towards stressors, and what is tolerated by some individuals may be detrimental to others. Therefore, the assessment of welfare in a few individuals may not represent the average welfare of a group and vice versa. This underlines the need to develop on-farm, operational behavioural welfare indicators that can be easily used to assess not only the individual welfare but also the welfare of the whole group (e.g. spatial distribution). With the ongoing development of video technology and image processing, the on-farm surveillance of behaviour may in the near future represent a low-cost, noninvasive tool to assess the welfare of farmed fish.

Keywords Fish behaviour - Well-being . Aquaculture - Operational welfare indicators . Mental states $\cdot$ Stress $\cdot$ Appraisal

\section{Introduction}

During the last decade, the issue of farmed fish welfare has raised increasing public and scientific concern. This has contributed to the development of policies related to fish welfare (e.g. Council Directive 98/58/EC and the recommendation on the welfare of farmed fish by the council of Europe in 2005). Stakeholders, welfare NGO's and scientists have long recognised the importance of welfare of farmed and captive animals; nevertheless, despite the increasing interest on fish welfare, there is no clear consensus on how fish welfare should be defined or assessed (Huntingford et al. 2006; Ashley 2007).

Most animal welfare definitions can be loosely categorised into 'function-based' or 'feeling-based' definitions. 'Function-based' definitions have the fundamental assumption that welfare is correlated with biological functioning including physiological stress responses (Duncan 2005), while in the 'Feelingbased' definitions, welfare more or less equals the current emotional state of the animal (Duncan and Dawkins 1983) and in the longer term, it represents the balance between positive and negative subjective experiences (Spruijt et al. 2001). The primary basis for the concept of 'animal welfare' is the belief that animals are sentient beings with an ability to experience good or bad feelings or emotional states (Dawkins 1990).

If the fish farmer wants to improve or document fish welfare, they need methods to assess animal welfare that can be feasible on a farm. A welfare assessment system should describe the welfare of farmed fish and allow the farmer to assess the development over time and to respond appropriately. Welfare indicators that are relevant for inclusion in an operational welfare assessment system should be science-based, should measure welfare over extended time periods, should be measurable on a commercial farm within a realistic framework and should be relevant as a decision support system for the farmer. To fulfil these requirements, the welfare indicators must provide information on potential welfare problems and the causes of impaired welfare (Rousing et al. 2001). Behavioural welfare indicators have the advantage of being fast and easy to observe and therefore good candidates for use 'on-farm'. Examples of behaviour that are commonly used as an indicator of welfare are changes in food-anticipatory behaviour, feed intake, swimming activity and ventilation rate (Huntingford et al. 2006). Such qualitative assessment can be converted into quantitative measures via video recordings and software for data collection, analysis and presentation, while image analyses facilitate continuous surveillance of behaviour. In this way, behaviour can be used as a noninvasive and as an early sign of potential welfare problems.

Disadvantages of behavioural welfare indicators can be that they are often variable over time and difficult to quantify, the observers need the sufficient skills to observe the animals 'body language', and there can be large individual differences in behaviour within animal groups. It is also worth noting that some behavioural responses can be considered 
normal coping activities and therefore contributing to welfare, while other responses may be considered abnormal or maladaptive, therefore hampering welfare. The differences between normal (i.e. part of an adaptive response) and abnormal behaviour are frequently unclear.

To make a robust scientific welfare assessment, other indicators are also needed, and using an integrated approach by combining behaviour, neurophysiology, pathological and molecular indicators may result in an improved welfare assessment (Huntingford et al. 2006).

Over the last few years, advanced biochemical and genomic technology has equipped researchers with robust tools for studying animals' coping systems, and the number of new welfare-related indicators has increased rapidly. Such scientific indicators vary from the measurement of cortisol excreted into water (reviewed in Scott and Ellis 2007 and Scott et al. 2008) into more complex approaches such as the upand down-regulation of targeted genes (e.g. Terova et al. 2005).

The aim of this review is to show that behaviour can be used to assess the welfare of farmed fish and to provide both aquaculturists and the scientific community with an overview of experimental results that show how certain behaviours can be applied as species-specific welfare indicators. We review behavioural changes whose link with welfare takes a more functional-based approach (foraging behaviour, ventilatory activity, aggression, individual and group swimming behaviour and stereotypic and abnormal behaviour) and those whose link takes a more feelingbased approach (exploratory behaviour, food-anticipatory activity, preferences and reward-related operant behaviour). Whenever the information is available, the link between behavioural indicators and other commonly used welfare indicators will be provided to allow a more comprehensive understanding of welfare assessment.

\section{The diversity of behavioural responses and coping styles}

Before addressing how specific behaviours can be used as welfare indicators, it should be noted that behavioural responses under stressful conditions are dependent not only on the type of stressor but also on the coping style that characterises an individual. Individual variation in responsiveness may explain why some conditions that are well tolerated by some individuals may be detrimental to others.

Koolhaas et al. (1999) defined coping style as a correlated set of physiological and behavioural traits consistently linked over time and across situations, which define the ability of the organism to cope with stress. There are two major types of coping styles: proactive (active coping or bold or 'fight-flight') and reactive (passive coping or shy or 'conservationwithdrawal'). Behaviourally, a proactive coping style is characterised by a high level of active avoidance, aggression, exploration, risk-taking and an active attempt to counteract the stressful stimulus as opposed to reactive coping style. Physiologically, the proactive coping style is characterised by low production of corticosteroid hormones in response to stress production, but high sympathetic reactivity, while the opposite is true for the reactive coping style (Koolhaas et al. 1999; Pottinger and Carrick 2001a; Øverli et al. 2007).

The presence of coping styles is now well recognised in fish (reviewed in Øverli et al. 2007), and its implication for aquaculture can be wideranging. One of the best examples of such implications comes from studies using selected lines of rainbow trout, Oncorhynchus mykiss, differing in stress responsiveness. Low cortisol responders (typical proactive individuals) were shown to exhibit higher growth rates as compared with high cortisol responders (Pottinger 2006; Trenzado et al. 2006). These authors attributed the growth disparity between the two lines to differences in competitiveness/aggressiveness. Low cortisol responders tend to win fights for social dominance (Pottinger and Carrick 2001b), which may provide them with a competitive advantage to access feed when fixed feeding regimes are used. In addition, low cortisol responders have lower feed waste, higher growth rates, higher feed efficiency and lower size variability as compared to high cortisol responders (Øverli et al. 2006a).

These selected lines of rainbow trout were also shown to differ in susceptibility to crowding stress. High-stress responders were shown to be more negatively affected by crowding than the low-stress responders (Trenzado et al. 2006). In addition, divergent coping styles have been shown to exhibit 
different susceptibility to diseases and inflammatory challenges (Mackenzie et al. 2009).

In general, individuals' coping styles will be related to the stress response of the fish, both the physiological response and the time lag before, e.g. recovering normal feeding (Damsgård and Dill 1998) and swimming behaviour after a stress event Øverli et al. 2006b). If a disturbance causes a fish to swim away or become inactive, such 'lost opportunities' will affect other behaviours, e.g. the time to feed. Small Atlantic salmon, Salmo salar, reduce their feeding activities for $2 \mathrm{~h}$ after a brief exposure to a trout model (Metcalfe et al. 1987). Also, Dill (1983) showed that the potential risk of predation for a juvenile coho salmon affected the distance the fish was willing to swim from the holding position to take a food item, and the fish seems able to trade-off the relative risk towards the relative value of the food. An individual boldness trait may thus affect where to feed, when to feed, how much time to allocate to feeding and the foraging tactics of the animal. In addition, other authors have also made the link between coping styles and traits relevant to aquaculture such as feed efficiency (e.g. Martins et al. 2006a, 2008).

Coping styles may also affect how fast fish might adapt to new feeding systems and explore new fish farm environments. A study on Atlantic cod, Gadus morhua, escaping from net cages revealed consistent individual differences between the fish escaping compared with nonescaping fish, with bold individuals being more willing to swim through small holes in the net, and thus escape more frequently than shy fish (Hansen et al. 2008). These responses are generally linked with the learning ability of farmed fish. In fact, Moreira et al. (2004) showed that lines of rainbow trout selected for high and low responsiveness to stress (HR and LR-lines) also differed in memory retention in addition to cortisol production.

An individual's responsiveness to stress is influenced by its coping style or behavioural syndrome, which should be considered when interpreting the variation in behavioural responses. The extent to which an individual is bold or shy should not be used as a welfare indicator, but one may infer a welfare problem when the behaviour defined under the bold/ shy continuum changes; for example, when a bold individual starts exhibiting typical shy behaviours such as decreased exploratory behaviour, one may suspect that it is sick or chronically stressed. Still, one should interpret such changes with care, as coping styles are considerably plastic and may change with context (e.g. Ruiz-Gomez et al. 2008).

\section{Behavioural welfare indicators}

\section{Foraging behaviour}

In the context of this review, foraging is defined as the search for and exploitation of food resources (Danchin et al. 2008). Foraging behaviour has been recorded in fish in terms of daily feed intake or feeding rate, the latency or time to start of feeding, total feeding time and the activation of self-feeders. Under ideal circumstances, an animal can reach reproductive age or (in case of aquaculture) harvesting age, without having to engage in any aggressive or territorial behaviour, but cannot do so without feeding (Dugatkin 2004). In fact, reduced appetite has been considered one of the main causes for growth reduction after stress exposure (Wendelaar Bonga 1997).

Teleost fish exhibit a wide variety of foraging strategies, which can be affected by the farming systems (Turnbull and Kadri 2007), gender (Øverli et al. 2006b), the genetic strain/family group (Kolstad et al. 2004; Kittilsen et al. 2009) and other factors. Variations in foraging behaviour include where fish feed (bottom feeders, surface feeders and feeding from the water column), when they feed (e.g. nocturnal vs. diurnal as well as scheduled vs. random), how they feed (active predators, scavengers or more passive feeders) and what they feed on (animal or vegetable matter or both). This variation should be taken into consideration when interpreting foraging behaviour.

One of the most relevant aquaculture procedures that have been linked with changes in foraging behaviour and welfare is the feeding method. The techniques for delivering food should be appropriate for the particular species (Alanärä and Brännäs 1996; Alanärä et al. 1998; Andrew et al. 2002; Noble et al. 2007b). For instance, bottom-feeding flatfish have been shown to have improved welfare (measured as feed intake and feeding motivation) when fed sinking pellets compared with floating pellets (Kristiansen and Fernö 2007). In addition, Sánchez et al. (2009) 
using sea bream, Sparus aurata, as a model showed that altering the feeding time (scheduled vs. random) affects behaviour and physiology. These authors highlight the importance of using scheduled feeding to allow fish to prepare themselves (both behavioural and physiologically) for the next, predictable, meal. Fish exhibited an increase in locomotory activity before feeding, i.e. food-anticipatory activity (see also section "Group swimming behaviour") when a scheduled feeding regime was used as opposed to fish receiving random feeding (Sánchez et al. 2009). However, imposed fixed regimes can increase the incidence of fin damage and injury as compared to demand feeding (Noble et al. 2007b, 2008), so a farmer should bear this in mind when making decisions on utilising a fixed ration or demand feeding strategy. In addition, the use of self-feeders has been shown to improve feed conversion ratio and growth in rainbow trout (Alanärä and Brännäs 1996) and can also be beneficial for their welfare (Suzuki et al. 2008).

Aquaculture stressors can reduce both feeding motivation and feed intake. The speed with which fish resume feeding after a stressor has been used as a foraging-related welfare indicator, for example in rainbow trout (Øverli et al. 2006a). Feeding motivation, measured as the latency to start feeding, has also been used as an indicator of welfare in Nile tilapia Oreochromis niloticus, cultured in recirculating aquaculture systems (Martins et al. 2009). More recently, Rubio et al. (2010) used self-feeders in sea bass, Dicentrarchus labrax, to understand the effects on refeeding dynamics after fish are exposed to fasting periods (which may occur before harvest). These authors showed that fasting periods can increase both feeding rate and daily feeding times.

In addition to changes in feeding behaviour, changes in feed intake have been repeatedly used as an indicator of reduced welfare. A variety of stressors have been shown to reduce feed intake in different fish species. Examples include changes in water quality (e.g. in Atlantic salmon, Espmark and Baeverfjord 2009; Nile tilapia, Martins et al. 2009; sea bass, Santos et al. 2010), stocking density (reviewed in Ellis et al. 2002 for rainbow trout), anaesthetisation and vaccination (e.g. in Atlantic salmon, Sørum and Damsgård 2004), establishment of dominance hierarchies (e.g. in Arctic char Salvelinus alpinus, Alanärä et al. 1998) as well as changes in the social structure of the groups as a consequence of grading or sorting procedures (e.g. in African catfish Clarias gariepinus, Martins et al. 2005, 2006b). In addition, cleaning protocols (such as emptying and brushing of the tanks) have been shown to impair self-feeding in sea bass (Rubio et al. 2010).

In brief, any observed changes in foraging-related behaviours, unless coupled with a change in management practices, is highly likely to be an indicator of changes in either the motivational state, health and/or welfare status of fish. This is supported by studies showing similar central signalling systems (corticotrophin-releasing factor, CRF/urocortin activation) involved in both stress-induced anorexia and negative emotions, at least in higher vertebrates (Heinrichs and Koob 2004). Whether this is also the case in fish still needs further study. Changes in foraging behaviour and behaviours associated with foraging can therefore be one of the most important behavioural operational welfare indicators of farmed fish species and are probably the indicator most commonly used by fish farmers. However, one cannot exclude the possibility that reduced feeding is also an adaptive response to a mild stressor or in some cases even a response to positive experiences.

\section{Ventilatory activity}

Ventilatory activity is the flow of water ventilated over the gills per unit time. It is performed by bucco-opercular movements. Its aim is the renewal of water in the branchial cavity, and a healthy fish will regulate it precisely. Ventilation ensures the supply of oxygen at the exact rate required by cellular oxygen $\left(\mathrm{O}_{2}\right)$ metabolism, neither too much nor too little. Specifically, the partial pressure of $\mathrm{O}_{2}$ in the blood leaving the gills must be regulated in a very low and narrow range, primarily to avoid oxidative stress at the cellular level. Certainly, a fundamental and central idea is that $\mathrm{O}_{2}$ deficiency in animal tissues is the result of a mismatch between $\mathrm{O}_{2}$ needs and $\mathrm{O}_{2}$ supply. The balance must be finely tuned, and ventilation must be taken as the first firewall protecting the fish tissues against oxidative stress (Massabuau 2001, 2003). Accumulated scientific evidence supports the concept that oxidative damage to tissues and cellular components is either a primary or secondary cause of many human diseases. Considerably less is known about how oxidative 
stress can affect animal health and well-being, but it is clearly a significant underlying factor related to dysfunctional host immune and inflammatory responses that can increase the susceptibility of any farmed livestock to a variety of health disorders (Sordillo and Aitken 2009). This must be definitively taken into account in fish farming (see for example Ritola et al. 2002; Kucukbay et al. 2006).

Counting the number of opercular movements (ventilatory frequency), and estimating their amplitude, provides an index of ventilatory activity. It is worth noting that besides laboratory tools, there are efforts to develop new field methods to record ventilatory activity by fish telemetry. SmartTags have been developed to measure ventilatory frequency and amplitude of free-swimming fish as an indicator of fish welfare (Damsgård 2008).

Well-balanced ventilatory activity is fundamental to maintaining homoeostasis in terms of $\mathrm{O}_{2}$ status, blood and tissue acid-base balance $(\mathrm{pH})$ at precise set points. In an acclimated and unstressed fish, the respiratory frequency is adjusted close to a minimum possible value. Therefore, increased ventilatory activity is commonly used as a sign of stress and poor welfare in fish. Importantly, it only takes a few seconds for a fish to change its ventilatory activity in response to water oxygenation or a chemical change. This is mediated by either chemoreceptors in the buccal cavity (taste buds, Ishida et al. 1996) or $\mathrm{O}_{2}$ chemoreceptors in the gill vascular bed (Burleson and Milsom 2003). How fast it returns to reference levels is fundamentally variable if the health status of the fish is altered. Following a brief water $\mathrm{O}_{2}$ change, it simply takes seconds (Eclancher and Dejours 1975).

Ventilatory activity can increase as a consequence of several aquaculture procedures or stressors. The key factors affecting ventilation activity include the levels of dissolved oxygen and carbon dioxide in the water with ventilatory activity being inversely related to water oxygenation. Frequency of ventilation increases up to a certain critical low oxygenation level after which it again decreases and the fish suffocate after a while. In contrast, the frequency of ventilation decreases when $\mathrm{O}_{2}$ is in excess (Randall 1982; Xu et al. 2006). It is known that a slight excess of dissolved carbon dioxide levels leads to variable ventilatory responses according to the water chemistry and the fish physiological status; a large excess can be narcotic resulting in decreased ventilatory activity (Osborne and Muntz 1906).

Several other biotic and abiotic factors have been linked with increased ventilator activity. These include artificial lighting, loud or aversive sound, arousing odours, unsuitable temperatures or substrates, restricted movement, reduced retreat space, forced proximity to humans, reduced feeding opportunities, manipulation of fish groups, transportation (e.g. Barreto and Volpato 2006; Morgan and Tromborg 2007), handling (Brydges et al. 2009), air exposure (White et al. 2008), the presence of predators (Barreto et al. 2003), presence of chemicals (Neely 1979; Israeli-Weinstein and Kimmel 1998; Pane et al. 2004; Scott and Sloman 2004), diseases (Byrne et al. 1991), nanotubes (Smith et al. 2007), cyanobacteria (Ernst et al. 2007) and poor water quality in general (ammonia $\left(\mathrm{NH}_{4}\right)$ /nitrate $\left(\mathrm{NO}_{3}\right)$ excess, etc.).

In addition, any environmental change stimulating ventilatory activity can increase the vulnerability of fish to toxic chemicals simply by increasing the gills exposure to these: ventilation increases the surface of ventilated gill lamellae, and it decreases the thickness of the unstirred boundary layers (Pierron et al. 2007; Couillard et al. 2008). The enhancement is stronger when the contaminant concentration is low because a very low concentration can then become significant in terms of exposure rate. A high concentration is always a problem because there is so much contaminant in the water that ventilatory activity is no longer a limiting factor.

In brief, during routine inspection, sustained hyperventilatory activity does not tell the observer much about the origin and/or intensity of a stressor (see Barreto and Volpato 2004) but, combined with other observations (such as location in the tanks or reactivity), it can be a sensitive indicator of fish welfare. Furthermore, correlations between increased ventilatory activity and other welfare indicators, such as blood lactate, glucose and haematocrit, are well established (e.g. White et al. 2008). Nevertheless, one should interpret an increase in ventilatory activity with caution as an increase may be linked with positive experiences and therefore not necessarily with poor welfare.

Importantly, considering the profound consequences ventilatory activity has on the homoeostasis of a fish's internal environment such as control of 
cellular oxygen status, oxidative stress and internal $\mathrm{pH}$ regulation, high ventilatory activity can be both a passive consequence of disturbances and a driver promoting various physiological dysfunctions and contaminations. The basic premise that 'ventilatory activity should be low to moderate' should help (1) to minimise the effects and consequences of disease and injury and (2) improve fish welfare.

\section{Aggression}

Fish in a natural environment can live alone or in groups (Brännäs et al. 2001). Group living can take the form of short-term aggregations or be more long term and highly structured (Pitcher and Parrish 1993; Grant 1997; Hoare and Krause 2003). Group living confers advantages in foraging, resource defence and predator detection (Pitcher et al. 1982; Ryer and Olla 1991, 1992; Pitcher and Parrish 1993), and shoaling is one of the most common social fish behaviours (Pitcher and Parrish 1993; Parrish et al. 2002; Hoare and Krause 2003). However, when resources or the number or territories are limited, group living becomes a disadvantage as competition for the resource increases (Pitcher and Parrish 1993). Limiting resources may lead to the emergence of competitive behaviours, which may take the form of dominance rank-based hierarchies (Jobling 1983; Jobling and Koskela 1996). This kind of hierarchy is generally established after agonistic encounters between two individuals, and the rank within the hierarchy depends on their ability to fight (Huntingford and Turner 1987). In this review, agonistic behaviours refer to 'all the behavioural units of threat that express the dominance between at least two social partners as well as the submission in response to it'. Agonistic behaviours include attacks, bites or bite attempts, threatening displays and behaviours related to submission such as flight or immobility.

Dominance hierarchies and the associated agonistic behaviours are dependent on several biotic and abiotic factors such as an individual's 'boldness' (see above), size or sex (Ejike and Schreck 1980), the spatial and temporal distribution of food (BégoutAnras and Lagardère 2004), underfeeding (Symons 1968), feeding frequency (Noble et al. 2007a) and feed delivery rate (Hakoyama and Iguchi 1997), with the latter factors being particularly relevant for aquaculture. The effects of stocking density upon aggression are still unclear, as some studies suggest that high density can reinforce aggressiveness (e.g. Keeley 2000), whereas others suggest that high density reduces aggression (e.g. Almazán-Rueda 2004; van de Nieuwegiessen et al. 2008, 2009).

A subordinate position within a group or social hierarchy may be a stressor (Schreck 1981). A subordinate individual can be subject to social stress resulting from attacks and repeated threats of attack from more dominant individuals for access to resources (food, sexual partners and territory). Social stress leads to marked behavioural and physiological changes in subordinates, who often show a general behavioural inhibition of food intake, aggressiveness, locomotory activity, changes in skin colorations and higher levels of plasma cortisol (Denight and Ward 1982; O'Connor et al. 1999; Winberg and Nilsson 1993a, b; Øverli et al. 1998). It is, however, notable that cortisol elevation can also occur in dominant fish within minutes of the end of aggressive encounters (Øverli et al. 1999).

Not only is the social state of an individual important for welfare but also the social stability of a group. Fox et al. (1997), for example, showed that cortisol levels are dependent on both individual dominance and social stability in the African cichlid fish Haplochromis burtoni.

Proxies of aggression can be used as an operational welfare indicator by counting the number of skin lesions. Almazán-Rueda et al. (2004) and Cañon Jones et al. (2010) showed a significant positive correlation between the number of scars and/or wounds and the number of aggressive acts measured by direct observation. Almazán-Rueda et al. 2004 also validated the use of skin lesion frequency to assess the welfare of African catfish in two studies (Almazán-Rueda et al. 2004; 2005) and showed that feeding methods, photoperiod and light intensity affect skin lesions frequency as well as other welfare indicators (such as swimming activity, growth, plasma cortisol and free fatty acids). Similarly, Martins et al. (2006b) used skin lesions as an indicator of aggression to assess the welfare of African catfish subjected to a simulated grading. Considering the time-consuming characteristics of direct or video-recording observations, counting skin lesions may be used as an easy and fast indicator of welfare, when it can be combined with other handling procedures. Although skin lesions serve as an 
indicator of poor welfare, aggression per se is not necessarily an indicator of poor welfare, unless coupled with lesions and fin damage. A consequence of this is that adjusting the aquaculture system to reduce aggression does not simply mean that one affects the aggressors' behaviour, but depending on the species, it may allow a certain level of aggression to occur while providing the target individuals with means to protect themselves.

The measurement of the nonapeptides vasotocin (AVT) and isotocin (IT) has also been suggested as an indirect way to measure aggression. AVT and IT are synthesised in hypothalamic neurones, from where they are transported to the neurohypophysis for storage and subsequent release. In fish, arginine vasotocin and isotocin have several functions, including being related to stressful conditions (Kulczykowska et al. 2009; Kleszczyńska et al. 2006; Mancera et al. 2008). Changes in hypothalamic, pituitary and plasma AVT/IT concentrations are found in many fish species subjected to different types of stress, e.g. confinement, disturbance, high density, food deprivation or rapid osmotic challenge, which are accompanied by aggressive acts. The AVT and IT response depends on both stress stimulus type and the level of aggression. In many teleost species, AVT has been shown to affect complex social behaviours such as courtship and territoriality (Semsar et al. 2001; Salek et al. 2002; Kleszczyńska et al. 2008), and the release of both AVT and IT is associated with different levels of sociality (Thompson and Watson 2004). Neuromodulatory actions of AVT and IT probably influence basic emotional regulatory mechanisms related to approach/withdrawal behaviours and aggression in social shoaling species. In Mozambique tilapia Oreochromis mossambicus, neurohormonal changes are different in dominant and subordinate individuals in social groups (Almeida et al. 2009). These authors suggest that the social stress activates the AVT system in the forebrain of subordinate males in this species, yet the pituitary and olfactory bulbs in both subordinate and dominant males are the areas associated with the highest levels of both neuropeptides. The outcome of social interactions influences the expression of subsequent social behaviour by changing the internal state of the individual affecting growth rates, breeding status and potentially affecting the welfare status (social stress) of the individuals. The changes in absolute levels of AVT and IT or the balance between them, associated with aggression, may reflect variations in internal state of the individuals. Taking into account a link between level of aggression and AVT/IT response, AVT and IT are proposed as specific neurohormonal measures of level of aggression.

Individual swimming behaviour

Swimming performance was defined by Beamish (1978) as an indicator of the progress of fish manoeuvring in water and is therefore an indicator of the ability of the fish to feed, escape predation and maintain position in a current (Beaumont et al. 1996). Some fish are strictly dependent on their swimming capacity in order to undertake migrations and achieve reproductive success (Plaut 2001; Wolter and Arlinghaus 2004).

Different swimming styles and activities have been classified by Beamish (1978) who distinguished (1) sustained swimming, where a fish is able to maintain a certain speed for long periods (over $200 \mathrm{~min}$ ), (2) prolonged swimming that is characterised by a shorter duration (between $20 \mathrm{~s}$ and $200 \mathrm{~min}$ ) and ends with fatigue and (3) burst swimming that can be maintained only for very short periods (under $20 \mathrm{~s}$ ). Burst swimming can also incorporate (a) elevated fast-start, high-energy swimming where fish rapidly accelerate from a resting position or a baseline swimming speed and (b) swimming manoeuvres that involve increased complexity and turning angles (e.g. Domenici and Blake 1997). Every swimming activity can be related to a particular swimming behaviour. Indeed, sustained swimming is characterised by low-frequency tail beats and a slow velocity (ca. one-third of maximum speed), while during prolonged swimming, fish can almost reach their maximum velocity (Lembo et al. 2007). Several different tests have historically been used to quantitatively evaluate the swimming activity of fish (Beamish 1978). The ones most widely applied to assess the physiological condition of fish are critical swimming speed, $U_{\text {crit }}$ (Wolter and Arlinghaus 2004), recovery tests (Farrell et al. 1998; Jain et al. 1998; Wagner et al. 2004) and muscular activity measured via electromyogram (EMG) (Cooke et al. 2000; McFarlane et al. 2004; Chandroo et al. 2005; Lembo et al. 2008) or remotely measured by physiological telemetry sensors. EMGs give a quantitative estimate of both swimming speed and metabolic costs of 
activity during swimming (mostly due to oxygen consumption). Thus, EMGs are a sensitive estimator of the metabolic scope for activity (SFA) (Fry 1971) and therefore, uniquely among these indicators, can be used as an operational, on-farm, welfare indicator by quantitatively measuring swimming activity of fish within cages or tanks.

Changes in swimming behaviour could reflect how a fish is sensing and responding to its environment. However, whether such changes can be used as an indicator of poor or good welfare are species and context dependent (Herbert and Steffensen 2005).

A number of common aquacultural water quality parameters can have an effect upon swimming behaviour. For example, reduced dissolved oxygen levels (hypoxia) can reduce the swimming speeds and activity of a number of species including white sturgeon Acipenser transmontanus (Crocker and Cech 1997) and Atlantic cod (Schurmann and Steffensen 1994; Herbert and Steffensen 2005). This reduced activity may enable fish to survive prolonged and widespread exposure to hypoxic conditions (Crocker and Cech 1997). In contrast, Tang and Boisclair (1995) have reported that the brook charr Salvelinus fontinalis increase swimming speeds in response to hypoxic conditions, and this is suggested to be an escape response from an area of potentially localised hypoxia. So, any deviations from normal, be it reduced or elevated, swimming speeds can be used as a potential indicator of hypoxia, although other water quality factors can have an effect upon swimming speeds (see below).

Hyperoxic conditions can also affect the swimming behaviour of fish. Atlantic salmon exhibit reduced swimming speeds (measured by reduced tail beat frequency) when held in superoxygenated water for prolonged periods (Espmark and Baeverfjord 2009). Other water quality parameters, in addition to oxygen levels, have been shown to affect swimming behaviour. These include low water $\mathrm{pH}$ levels (Day and Butler 1996), increased ammonia levels (Shingles et al. 2001), carbon dioxide exposure (Conte 2004) and trace element exposure (Hopkins et al. 2003).

A number of feed management factors can have an impact upon swimming behaviour, but their effect upon welfare can be rather unclear as elevated swimming speeds can again be indicative of both reduced and improved fish welfare, depending upon the fish species and rearing conditions. For example, elevated swimming speeds during feeding can indicate underfeeding in a number of aquacultural species such as gilthead sea bream (Andrew et al. 2004), turbot, Scophthalmus maximus (Huse and Skiftesvik 1985) and Atlantic cod (Björnsson 1993). However, increased swimming speeds during feeding may also indicate an increased motivation to feed and may simply be part of an individual's foraging strategy. For example, Atlantic halibut, Hippoglossus hippoglossus, which may be classified as a sit and wait forager, responds to feed by increasing their swimming activity (Kristiansen and Fernö 2007). This potential dichotomy of how a single behaviour can be interpreted as either poor or good welfare is a good example of how farmers and researchers should develop species-specific welfare indicators based upon the feeding ecology of the species under investigation.

Feeding regime can also affect swimming speeds and manoeuvre complexity irrespective of whether fish are fed to satiation or not. For example, cage-held Atlantic salmon parr and smolts exhibited increased swimming speeds and performed sharper turns during feeding when they received a uniform, temporally predictable ration to perceived daily satiation. However, fish fed to daily satiation using demand feeding technology did not significantly change their swimming speeds and performed moderate turns during feeding (Noble et al. 2007b, c). Fish can also exhibit increasingly complex swimming manoeuvres during feeding in response to underfeeding (Andrew et al. 2004). However, the same study also found that manoeuvre complexity increases with a high feed delivery rate irrespective of ration size, and the authors suggested that this behaviour allows the fish to remain within the feed delivery area (Andrew et al. 2004). Therefore, the same behaviour within the same species can be indicative of both poor welfare (underfeeding) or may simply be a foraging strategy to maximise an individual's feed intake. Further, a high feed delivery rate may reduce an individual's swimming speeds during feeding, as fish switch from swimming to processing and handling prey as feed encounter rate increases (e.g. Priyadarshana et al. 2006). In addition, increases in long-term EMG profiles (obtained via an EMG transmitter calibrated using a hard-wired EMG during $U_{\text {crit }}$ tests) were also observed as consequences of the administration of 
three diet formulations (organic vs. conventional) (Carbonara 2009) and in experiments evaluating the consequences of starvation (McFarlane et al. 2004).

Behaviour modifications in response to pathogens, parasites and pollutants have been well documented by the industry and in the scientific literature. These include increased activity, such as flashing on the water surface, as well as decreased activity and lethargy (Warren 1982). Altered host behaviour as a consequence of infection may be an important criterion for identifying infected fish that are experiencing reduced welfare. Disease is detrimental to swimming performance in sockeye salmon, Oncorhynchus nerka (Tierney and Farrell 2004), and bull trout, Salvelinus confluentus (Jones and Moffitt 2004). An increased parasite load can also reduce swimming performance in Atlantic salmon (Wagner et al. 2003). Mycobacterium-infected delta smelt, Hypomesus transpacificus, also showed a $20 \%$ reduction in swimming performance during $U_{\text {crit }}$ tests (Swanson et al. 2002). However, a wide range of parasites only impact significantly upon the host swimming behaviour patterns when they reach a certain developmental stage or infection intensity threshold; thus, changes in individual swimming behaviour can be correlated with severe infections and could potentially indicate poor welfare (Barber 2007). In addition, injuries such as lordosis (Basaran et al. 2007) can also be detrimental to swimming performance. Therefore, reduced swimming speeds or occasions where fish cease schooling and become immobile or inactive can also be an indicator of fish being sick, a disease outbreak, increased parasite load or an indicator of injury in farmed fish.

Fish can also increase their swimming speeds in response to increased stocking density, e.g. rainbow trout (Cooke et al. 2000) and Atlantic halibut (Kristiansen et al. 2004). Similarly, EMG profiles showed that sea bass reared at higher stocking density used on average $25 \%$ more energy than at lower stocking density (Scolamacchia 2009). Other common aquacultural procedures, such as handling, chasing, air exposure and changes in light conditions, can also lead to elevated swimming speeds in Atlantic salmon and sea bass (FASTFISH 2009). Further, EMG monitoring was demonstrated to be an effective indicator of fish welfare for investigating energetic responses and stress levels related to transportation in rainbow trout (Chandroo et al.
2005). In fact, a significant posttransportation swimming activity increment was recorded. Furthermore, after a recovery period of $48 \mathrm{~h}$, the oxygen consumption level continued to be significantly elevated, and the swimming performance (measured as critical speed and endurance) of the transported fish was still impaired. Poli et al. (2005) also reported increased swimming speeds during both crowding procedures and slaughter using $\mathrm{CO}_{2}$ narcosis. Continuous lighting can increase swimming activity in African catfish (Almazán-Rueda 2004), while the type of rearing systems can have an impact upon swimming speeds. Recent research has shown that Atlantic salmon reared in submerged cages for both short- and longterm submergence periods increase their swimming speeds, which may be a strategy allowing them to cope with reduced buoyancy (Dempster et al. 2009; Korsøen et al. 2009).

In summary, farmers and researchers should have a thorough knowledge of fish swimming activity under normal rearing conditions, noting any short-term changes in swimming, such as reduced or elevated swimming speed or increased manoeuvre complexity, as an acute indicator of potentially detrimental welfare conditions. Fish farmers can monitor swimming activity using, for example, telemetry techniques associated with remote sensors (in cages or tanks) and cameras. Possible strategies to maintain normal swimming activity could be related to appropriate water qualities and stocking densities for each species, appropriate feeding regimes and satisfactory disease prevention.

\section{Group swimming behaviour}

Cultured fish are reared in large numbers at high densities, and it is impossible to assess the behaviour or welfare of all individuals. Assessments of group behaviour can be used as an operational on-farm welfare indicator and are what most fish farmers use daily to evaluate the hunger, stress level and health status of fish. Group swimming behaviour is defined as the spatial distribution and swimming activity of groups of fish held within an aquaculture production unit and covers shoal structure, polarisation, the horizontal and vertical distribution of the group and their swimming speed and direction. A shoal is defined as a group of fish that remain together 
voluntary, while synchronised and polarised fish shoals are termed schools (Pitcher and Parrish 1993).

The motivational state of an individual or the tendency to perform certain behaviours will vary with its internal affective and physiological states, which again is a result of external and internal sensory and neuroendocrine signals and the subjective appraisal of these. The motivational state or welfare state of the fish will affect the 'traffic rules' used by the fish, which also should give observable changes in the group swimming behaviour and emergent properties of the whole group, which can be used as indicators of stress level or welfare. Model studies have shown that only one fish with different 'traffic rules' can affect the behaviour of the whole group (Romey 1996), indicating that this can be a sensitive indicator if we are able to correctly interpret the behaviour.

When held at high density, individual fish have to respond to the behaviour of others, and the group can adopt polarised schooling just by swimming in a way that minimises the risk of collisions (Føre et al. 2009). Polarity, group velocity and interindividual spacing are characteristics of fish shoals that strongly affect individual members (Pitcher and Parrish 1993, Parrish et al. 2002). These characteristics are grouplevel 'emergent properties': collective outcomes of behavioural interactions among members, not under direct control of any single member. Simulation models show that many of the different emergent structures can be explained by forces that act on each individual and are modulated in response to other individuals' behaviour. Examples of forces include the following: biomechanical drag, aggregative attraction and repulsion and arrayal velocity matching (Parrish et al. 2002).

Farmed species are chosen because of their ability to thrive at high densities. In fish tanks and cages, there will usually be areas that are more favourable than the others and restricting these volumes will result in a trade-off between packing density (number of fish per cubic metre, Juell and Fosseidengen 2004) and environmental conditions. Especially in sea cages, there can be large environmental gradients, with highly variable temperature, salinity, oxygen, current speed and light conditions (Juell 1995, Juell and Fosseidengen 2004, Johansson et al. 2006, 2007, Oppedal et al. 2007). Fish are attracted to the most optimal areas and avoid the unfavourable ones as a result of both attractions to a part of the rearing volume with preferred environmental conditions and avoidance/repulsion from areas with poor environmental conditions. Such conditions cause a trade-off between packing density and the benefits of being in the relatively best areas, and at high stocking densities, the less competitive fish will be forced to stay in suboptimal areas (Juell 1995, Johansson et al. 2006, Oppedal et al. 2007). The behaviour of the fish can also have an effect on environmental conditions, and the high local concentrations of fish can cause reduced water flow and increased oxygen consumption leading to areas with hypoxia. Frequent profiling measurements of these conditions are necessary to relate the behaviour to environmental conditions.

In most fish species, exposure to negative stimuli leads to rapid escape movements towards the bottom of the tanks or cages, and concentration of the group near the bottom can indicate relatively recent exposure to acute stressors (Stien et al. 2007, FASTFISH 2009; Bratland et al. 2010).

In situations of acute stress, the fish react initially with reflexes that transmit through the shoal by fish copying or matching the behaviours of their nearest neighbours (Føre et al. 2009). In salmon cages, it is possible to observe strange emergent structures like fast swimming in 'tornados' or 'hour glass behaviour' of streams of fish moving fast from one location to another, which is also seen in wild fish schools stressed by predators (Pitcher and Parrish 1993). This is probably caused by copying behaviour, confusion and cognitive demands on the individuals, which then surrender their control to that of the school. Emergent structures can also spread to unstressed fish since this behaviour itself signals danger and can cause stress. However, similar (but not equal) behaviour can also be a positive indicator of high-feeding motivation (in sea bass), so these indicators differ according to species, life stage and rearing method.

A common indicator of good health and coping ability is the anticipatory response of the fish to feeding and sounds or signals associated with feeding. In aquaculture cages and tanks, this can be shown as a high concentration of fish near the feeding area and increased schooling activity (Juell et al. 1994, Chen and Purser 2001). A good feed anticipatory response and feed intake can be signs of high feeding motivation and unstressed fish (Fernö et al. 1995, 2006; Folkedal 2010). Experiments with salmon subjected to classical conditioning showed 
that the anticipatory response after giving a conditioned signal was affected by acute stress, and the time for recovery to normal baseline behaviours was longer than the period of elevated cortisol levels (Stien et al. 2007, Bratland et al. 2010). However, increased swimming activity prior to and during a meal can also be a sign of underfeeding or a poorly designed feeding regime (e.g. Andrew et al. 2004; Noble et al. 2007b, c). Therefore, care must be taken to avoid underfeeding as the ensuing feeding frenzy could be interpreted as a positive indicator of welfare.

\section{Stereotypic and abnormal behaviour}

Mason (1991) described stereotypic behaviour as a behavioural pattern that is repetitive, invariant and with no obvious goal or function. This definition has been revised following several studies that suggest stereotypic behaviour has an adaptive goal as it allows, for example, an increase in opioid activity that provides individuals with a reward experience (e.g. Cronin et al. 1986).

Observations of stereotypic behaviour and other abnormal behaviours have been subjected to intense study in zoo animals (Mason and Rushen 2006) and terrestrial farm animals (Von Borell 1995), and it is repeatedly used as an indicator of poor welfare. The link between the appearance of stereotypic behaviour and poor welfare seems obvious when it results in physical injury or arises during suboptimal housing and rearing conditions. However, this link is not so clear cut as these repetitive behaviours may generate positive (reward) feelings as part of a coping strategy and therefore be compatible with good welfare (Dawkins 1998). Despite the debate on stereotypic behaviour and feelings, it is generally accepted that the development of stereotypes arises as a response to frustration, discomfort or a conflict of motivation (Würbel and Stauffacher 1997).

There is very little evidence of stereotypic behaviour in farmed fish. Almazán-Rueda (2004) distinguished two stereotypic patterns in African catfish, which swim continuously and compulsively in fixed circular or triangular patterns of $10-50 \mathrm{~s}$ or $60-240 \mathrm{~s}$. Both Almazán-Rueda (2004) and van de Nieuwegiessen et al. (2008) demonstrated that African catfish stereotypic behaviour can be used as an indicator of reduced welfare or chronic stress (related to stocking density). Kristiansen et al. (2004) also reported stereotypic behaviour in Atlantic halibut, described as loops of vertical swimming behaviour. These authors showed an increase in stereotypic behaviour when halibut was kept at high stocking densities. Atlantic halibut were shown to develop stereotypic behaviour in shallow tanks and also when fed floating pellets instead of sinking pellets (Kristiansen et al. 2004, Kristiansen and Fernö 2007), suggesting that the rearing system and feeding method may act as chronic stressor in flatfish.

Other behaviours described as abnormal or a kind of stereotypic behaviour have been identified in Atlantic salmon (e.g. types of circular shoaling in cages Kristiansen et al. 2004) and Mozambique tilapia (e.g. vacuum pit digging when housed in the absence of substrate, Galhardo et al. 2008).

Despite the scarcity of literature, the appearance of stereotypes has been linked with aquaculture procedures and stressors and therefore can be an indicator of poor welfare in farmed fish.

\section{Mental states and possible associated welfare indicators}

The data reviewed thus far show that the majority of studies on fish welfare have been focused on identifying behavioural indicators of poor welfare (summarised in Table 1). Very little has been done both on identifying indicators of good welfare and on developing strategies to improve the welfare of farmed fish. The possibility that fish are sentient creatures and capable of affective states or feelings will contribute not only to strategies for avoiding poor welfare but also for promoting good welfare.

Feelings are evolved emergent properties arising from the central nervous system, which interfere with memory and learning processes, providing higher flexibility and better responses to dangers, thus increasing fitness (Broom 1998; Dawkins 1998). In other words, the negative and positive valence of stimuli interpreted in a conscious domain may play an important role in the mechanisms of getting what animals need and avoiding what they do not need. The emergence of consciousness in fish has been a matter of intense scientific debate (e.g. Rose 2002; Chandroo et al. 2004a, b). Some authors, e.g. Rose (2002, 2007) and Cabanac et al. (2009), argue that 


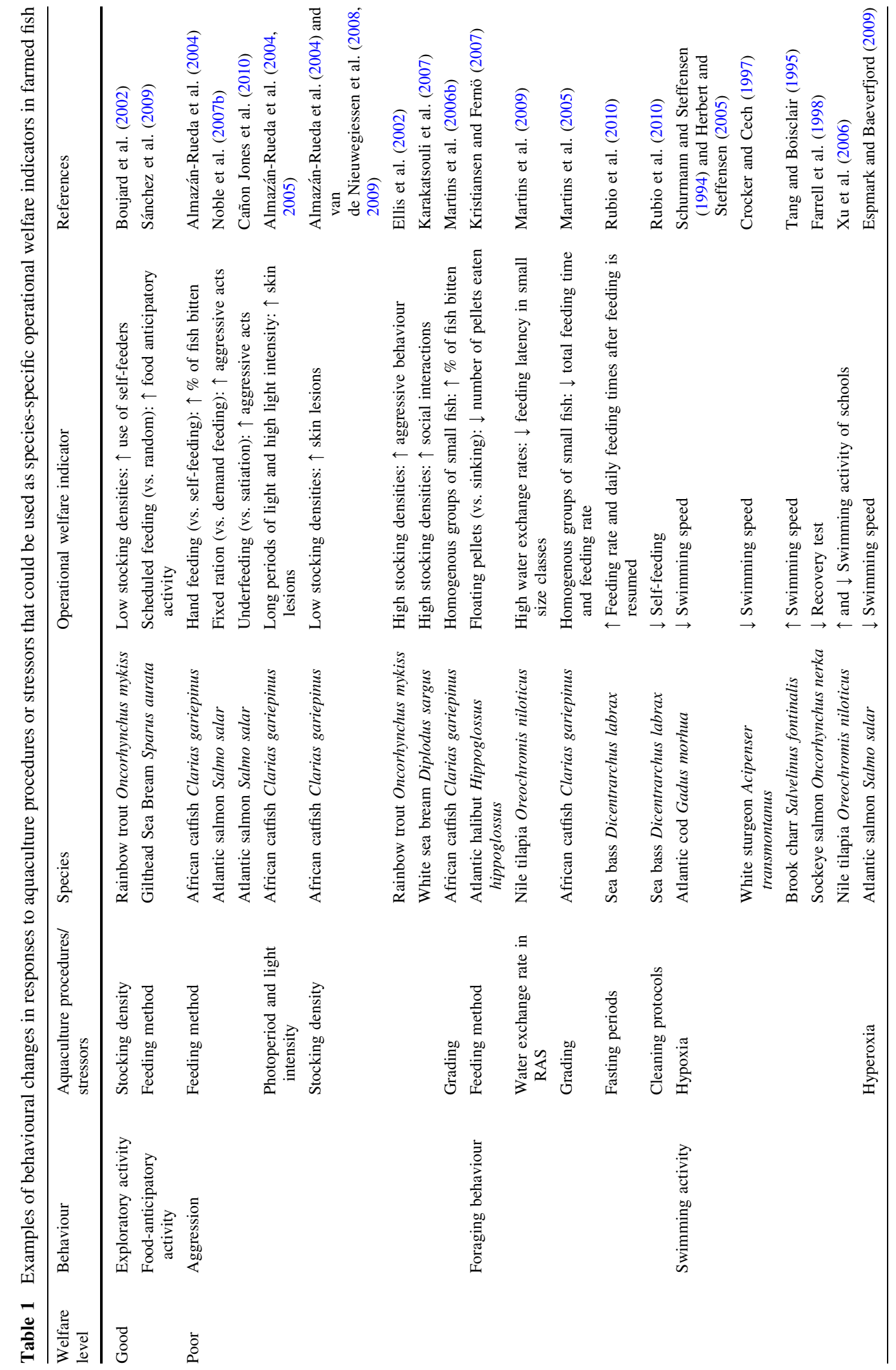




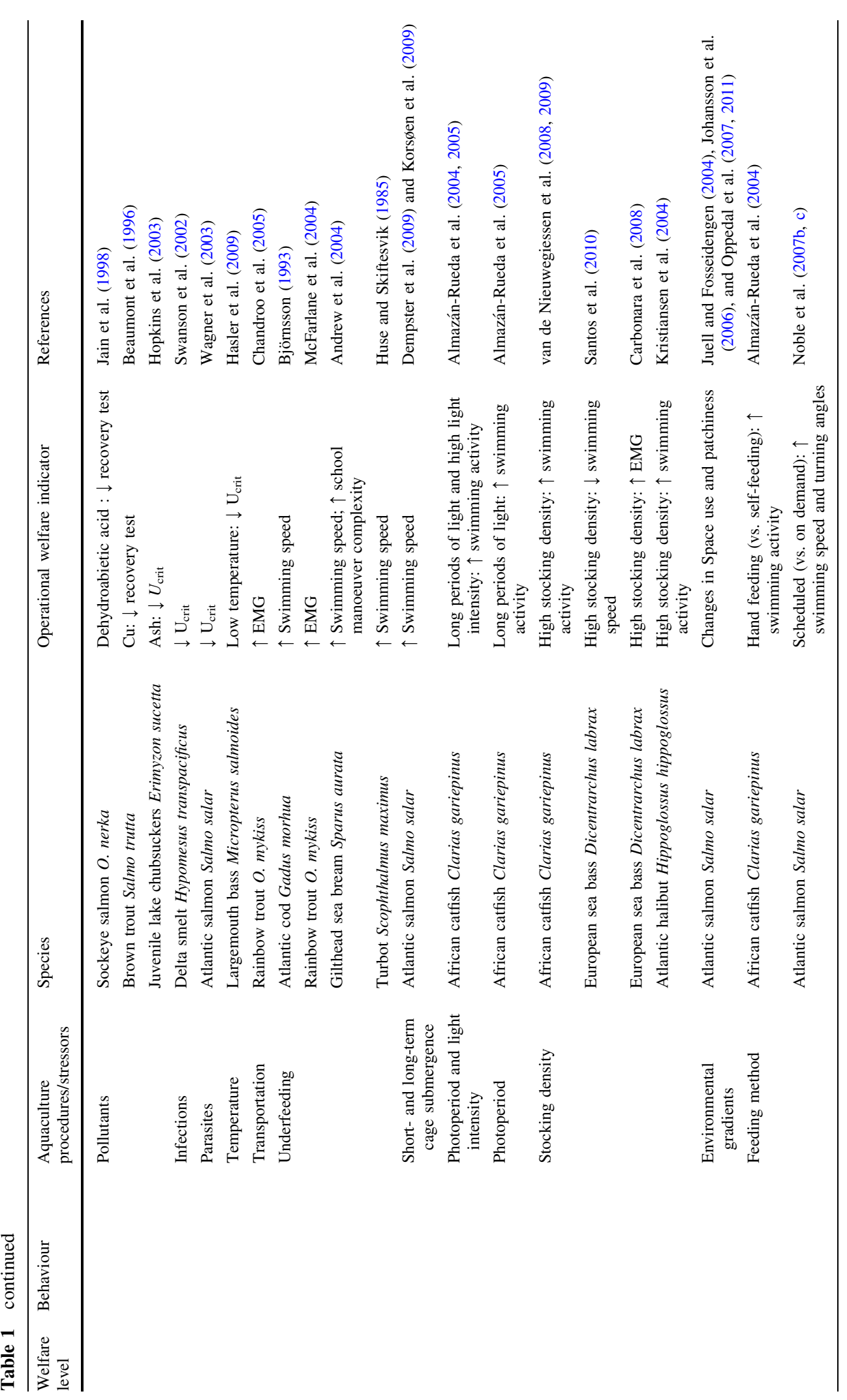




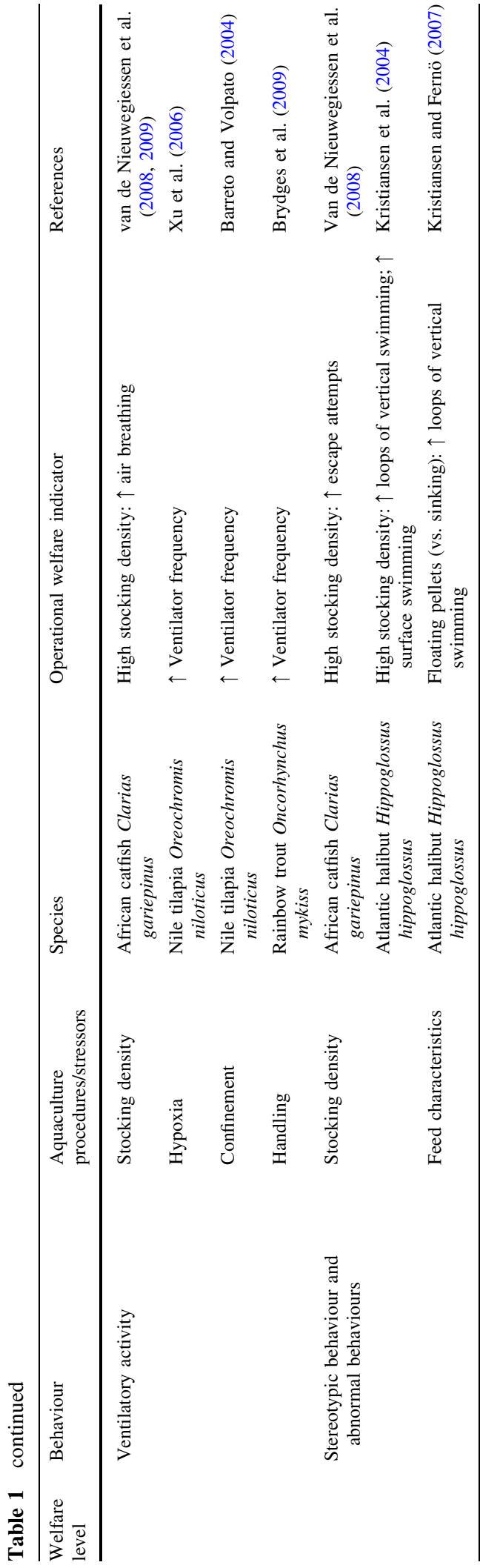

this is not possible because their behaviour is simple and reflexive and they lack a neocortex. Yet, a growing body of evidence related to cognitive (Braithwaite 2006), neuroanatomic (Portavella and Vargas 2005; Rodriguez et al. 2006) and emotional (Sneddon 2007; Yue et al. 2008) aspects of fish behaviour provides strong support for sentience (the ability to feel) in fish. Good welfare should therefore be related to behaviours associated with attraction and positive anticipation and reward behaviour, while bad welfare should be associated with frustration, aversion, fear, pain and sickness behaviours.

The measurement of exploratory behaviour, foodrelated anticipatory activity (reward anticipation), preferences and reward-related operant behaviour has been suggested as indicators of positive fish emotions and welfare (Galhardo 2010; Galhardo et al. 2011a). Exploratory behaviour has been suggested to be selfrewarding, increasing the predictability of, and control over, the environment (Schulze Westerath et al. 2009). These characteristics have led exploratory behaviour to be proposed as a candidate for assessing positive welfare in terrestrial farm animals (Schulze Westerath et al. 2009). In farmed fish, very little has been done on assessing positive welfare. Indirect suggestions come from the effect of stressors on the use of self-feeders. Boujard et al. (2002), for example, showed that increased stocking densities of rainbow trout reduced the number of operant tasks (use of self-feeders) executed to obtain a fixed food reward. Other examples, although not in an aquaculture context, come from exposing rainbow trout to noxious stimuli, which has been shown to affect an individual's exploratory behaviour (Sneddon et al. 2003). In addition, Galhardo (2010) showed a reduction in neophobia when Mozambique tilapia are kept under stable social conditions, further supporting the use of exploration behaviour as a tool to assess (positive) welfare.

In certain species and under certain conditions, food-anticipatory activity can also be an indicator of good welfare (Kristiansen and Fernö 2007), as it may indicate a behavioural priority for foraging instead of being hidden or trying to escape. Increased swimming activity around feeding areas prior to feeding time is often observed in fish farms. This foodanticipatory activity may allow fish to predict the exposure to appetitive stimuli and have some awareness of control, which have been suggested to be 
important appraisal modulators of the fish responses to their environment (Galhardo et al. 2011b).

Preference tests that allow animals to display their needs (Dawkins 2004) are used to assess fish welfare. Galhardo et al. (2009) showed that the lack of substrate is likely to decrease the welfare of breeding males in Mozambique tilapia. This approach considers that good welfare may not be equitable in all individuals. Indeed, recent studies suggest that stress response variability does not only depend on the individual's situation but also its cognitive evaluation of the situation, i.e. the way the stressor is appraised (Galhardo et al. 2009). Such knowledge could contribute to practical applications in animal production, of enhancing positive experiences and long-term positive emotional states, and including positive welfare indicators in on-farm monitoring systems (Boissy et al. 2007).

Reward-related operant behaviours are less used in fish welfare studies. However, Galhardo et al. (2011a) has shown how Mozambique tilapia can push a door in order to access different resources, where the degree of motivation to obtain food or social contact was clearly higher than for access to a suitable substrate.

Promoting positive welfare includes, for example, providing opportunities for exploration, which requires complex environments. Environmental enrichment aims to increase the environmental complexity in its physical, temporal and/or social dimensions. Physical complexity includes structural, visual, auditory, olfactory and gustatory stimuli, whereas temporal complexity refers to the degree to which physical stimuli changes (Carlstead and Shepherdson 2000). These levels of complexity are often missing in an aquaculture context. Indeed, when compared with the environment occupied by their wild conspecifics, intensively farmed fish are kept under highly standardised conditions, which often mean a complete lack of enrichment. Farmed fish are cultured for long periods of time in the same tanks of the same colour(s), the same shape and exposed to the same, potentially harmful, background noises. They are fed with the same diets, which have the same taste, same colours and often given at the same time of the day. In addition, appropriate social complexity is of paramount importance for some species, and often, the group size and composition are altered via grading or sorting procedures. If welfare-friendly housing systems are to be developed for farmed fish, we first need to understand the consequences of environmental enrichment on fish behaviour, physiology and performance. This information is scarce in farmed fish. Galhardo et al. (2008) showed that the use of tank substrate affects the reproductive behaviour and physiology, including behavioural needs (see below), in Mozambique tilapia males. Höglund et al. (2005) showed that providing hiding materials affects the fear response to alarm cues from conspecifics in crucian carp, while tank design and colour have also been shown to improve farmed fish welfare (Ross et al. 1995; Karakatsouli et al. 2007). The use of feeding systems or regimes that deliver a responsive ration in relation to appetite levels can also improve welfare by reducing the chances that fish are underfed (Suzuki et al. 2008), by reducing competition (Andrew et al. 2002; Noble et al. 2007b) and by reducing the frequency of injury and damage (Noble et al. 2008; Suzuki et al. 2008). Juell and Fosseidengen (2004) suggested the use of underwater lamps to avoid crowding and improve the welfare of caged Atlantic salmon. The efficacy of these and other strategies for routine use in aquaculture needs further verification, particularly the impact of environmental enrichment on maintenance and water quality.

The assessment of frustrated behavioural needs is related to indicators of poor welfare (Ashley 2007). Galhardo et al. (2009) showed that Mozambique tilapia perform vacuum pit building in the absence of appropriate substrate, which, under normal circumstances, males use to build their spawning pits. Behavioural integrity, in which animals should be allowed to perform their natural repertoire of behaviour to guarantee their welfare, has also been assessed as an indicator of poor welfare (Würbel 2009). Despite the recognition that an aquaculture environment differs significantly from natural habitats, with a questionable biological relevance of some of the fish behavioural repertoire under natural conditions, natural fish behaviour has generally been used as an indicator of fish welfare. Foraging and swimming behaviours are examples of natural behaviours that have been taken into consideration in aquaculture procedures. As mentioned above, flatfish are bottom feeders and show improved welfare when fed sinking pellets as compared to floating pellets (Kristiansen and Fernö 2007). The swimming behaviour of certain species, such as flatfish, has led to novel tank design, 
for example raceways to maximise the surface area, and allow flatfish to rest on the bottom, indeed, when denied access to a resting area flatfish develops stereotypic behaviour, while schooling salmonids, sea bream and sea bass need to swim constantly and are often cultured in circular tanks.

There is still room to introduce new techniques or strategies in order to improve the welfare of farmed fish. One of the most obvious approaches is to adapt the rearing systems not only to the physiological but also to the species-specific behavioural needs. At present, the production of the most relevant European farmed fish (i.e. Atlantic salmon, sea bream and sea bass) utilises technology that allows fairly good growth and survival rates, while the welfare level, including the mental dimension, of these species remains unclear. This is partly because there is still a lack of knowledge on the basic principles of behavioural, physiological and cognitive responses to stress under captivity. The basic question 'what is it like to be a fish under aquaculture conditions' remains to be answered. Thus far, the scientific community has made considerable efforts to understand what causes stress and how a stress response can be characterised in farmed fish. However, the future calls for answers to questions such as when is a potential stressor a real stressor, for how long a stressor remains a stressor, why is a stressor interpreted as such and why different individuals react differently to the same stressor?

An emergent area of fish research is the understanding of psychological mediators of stress. For example, predictability has been suggested as a tool to manipulate the way animals interpret stimuli or stressors (Wiepkema 1987; Greiveldinger et al. 2009; Veissier et al. 2009). This suggestion is supported by studies in rats that showed that the predictability of negative events (such as electric shocks) leads to a reduction in gastric ulcers as compared to rats that cannot predict the shock event (Guile 1987). Predictability of negative stimuli such as noise (Prior 2002) or introduction into an unfamiliar cage (Muir and Pfister 1986) has also been shown to result in reduced stress responses and better learning abilities in rats (Muir and Pfister 1986; Orsini et al. 2002; Prior 2002). Carlstead (1986) showed a positive effect of predictability of feeding on growth and aggressive behaviour in pigs, while the predictability of a sudden event was shown to lower subsequent emotional responses in sheep (Greiveldinger et al. 2007). These results encourage the use of predictability to improve farm animal welfare. Very little is known about the effects of predictability on fish. Galhardo et al. (2011b) showed that Mozambique tilapia subjected to predictable confinement exhibit lower cortisol levels than fish that could not predict such stimuli. The relieving effects of predictability have been suggested to rely on a sense of both safety during periods of nonsignalisation and control by allowing selfpreparation for the future events (Orsini et al. 2002; Bassett and Buchanan-Smith 2007). However, the use of highly predictable environments may lead to a hypostimulation of the HPI axis as a consequence, resulting in a situation that may be considered analogous to boredom (Wemelsfelder 1993).

The incorporation of concepts such as stability through change, i.e. allostasis (Korte et al. 2007), coping strategies (Øverli et al. 2007), appraisal and cognition (Galhardo et al. 2009) in farmed fish welfare will certainly allow a more comprehensive picture of how farmed fish welfare should be assessed, utilising both positive and negative indicators.

\section{Conclusions}

Behaviour represents a reaction to the environment as fish perceive it and therefore is a key element of fish welfare. In a developing and increasingly competitive aquaculture industry, it is of paramount importance that both farmers and researchers use species-specific behavioural signals for an early assessment of poor fish welfare. Furthermore, when considering the potential dichotomy of how behaviour can be interpreted as either good or poor (e.g. individual swimming activity) depending on the fish species, it is essential to develop an a priori understanding of the species-specific biology before drawing any conclusions in relation to welfare. Whether the same behavioural welfare indicator can be consistently used, and means the same throughout the life cycle of a fish, also needs to be addressed by future research.

It is also worth noting that fish differ in their coping strategies and perception of external events. Therefore, while one individual may interpret a situation as being highly stressful, another may interpret it as mildly stressful or even not at all stressful. Such 
variation in individual responses may make an overall assessment of welfare difficult. However, with the ongoing development of underwater video technology and computer image processing, the possibility of sampling high number of individual fish at a low cost will fall increasingly within reach. Another alternative is to develop group-based welfare indicators, such as spatial distribution.

The variability in coping strategies between individuals also emphasises that not all individuals within a group will have a good welfare status. In fact, group-based indicators may hide poor welfare at an individual level. Providing the culture environment with some sort of modifications (e.g. providing escape routes, hiding places, etc.) may help synchronise the culture environment with the inherent individual variability in stress responses present in farmed fish.

The interpretation of the meaning of behavioural changes in terms of welfare will also demand the willingness to accept that these changes are influenced by other factors besides the stressor itself, including mental states. Accepting that fish can be subjected to psychological stress will contribute to the development of strategies (e.g. environmental enrichment or allowing fish to predict or anticipate changes in the environment) that contribute to good welfare practices under aquaculture conditions.

If the interpretation of welfare in commonly reared farmed fish has yet to be resolved, the welfare of new fish species for aquaculture is even more incipient. There are at present a number of new fish species being considered for fish farming, such as the bluefin tuna Thunnus thynnus and the sparid common dentex Dentex dentex. While much attention is being placed on larval/broodstock and grow-out technologies, little has been done on the needs of these species that may have an impact on their welfare. Using the same technologies and rearing systems already in use for other fish species may not be enough to ensure the welfare of these new fish for aquaculture.

Acknowledgments This publication benefits from participation of authors in COST action 867 'Welfare of fish in European aquaculture'. The authors would like to acknowledge Øyvind $\varnothing$ verli for commenting on the link between coping styles and welfare indicators. Pino Lembo and Pierluigi Carbonara are gratefully acknowledged for their comments on swimming activity and welfare. C. I. M. Martins acknowledge financial support by Fundação para a Ciência e Tecnologia, Portugal, through the grant SFRH/BPD/42015/ 2007.

Open Access This article is distributed under the terms of the Creative Commons Attribution Noncommercial License which permits any noncommercial use, distribution, and reproduction in any medium, provided the original author(s) and source are credited.

\section{References}

Alanärä A, Brännäs E (1996) Dominance in demand-feeding behaviour in Arctic charr and rainbow trout: the effect of stocking density. J Fish Biol 48:242-254

Alanärä A, Winberg S, Brännäs E, Kiessling A, Höglund E, Elofsson U (1998) Feeding behaviour, brain serotonergic activity levels, and energy reserves of Arctic char (Salvelinus alpinus) within a dominance hierarchy. Can J Zool 76:212-220

Almazán-Rueda P (2004) Towards assessment of welfare in African catfish Clarias gariepinus: the first step. $\mathrm{PhD}$ thesis, Wageningen University, $160 \mathrm{pp}$

Almazán-Rueda P, Schrama JW, Verreth JAJ (2004) Behavioural responses under different feeding methods and light regimes of the African catfish (Clarias gariepinus) juveniles. Aquaculture 231:347-359

Almazán-Rueda P, van Helmond ATM, Verreth JAJ, Schrama JW (2005) Photoperiod affects growth, behaviour and stress variables in Clarias gariepinus. J Fish Biol 67: 1029-1039

Almeida OG, Kulczykowska E, Oliveira RF (2009) Changes in brain Arginine-vasotocin and Isotocin levels in dominants and subordinates males of cichlid fish. Society for neuroscience annual meeting, Chicago. Poster session 466.6

Andrew JE, Noble C, Kadri S, Jewell H, Huntingford FA (2002) The effect of demand feeding on swimming speed and feeding responses in Atlantic salmon Salmo salar L., gilthead sea bream Sparus aurata L. and European sea bass Dicentrarchus labrax L. in sea cages. Aquacult Res 33:501-507

Andrew JE, Holm J, Kadri S, Huntingford FA (2004) The effect of competition on the feeding efficiency and feed handling behaviour in gilthead sea bream (Sparus aurata L.) held in tanks. Aquaculture 232:317-331

Ashley PJ (2007) Fish welfare: current issues in aquaculture. Appl Anim Behav Sci 104:199-235

Barber I (2007) Parasites, behaviour and welfare in fish. Appl Anim Behav Sci 104:251-264

Barreto RE, Volpato GL (2004) Caution for using ventilatory frequency as an indicator of stress in fish. Behav Process 66:43-51

Barreto RE, Volpato GL (2006) Ventilatory frequency of Nile tilapia subjected to different stressors. J Exp Anim Sci 43:189-196

Barreto RE, Luchiari AC, Marcondes AL (2003) Ventilatory frequency indicates visual recognition of an allopatric predator in naïve Nile tilapia. Behav Process 60:235-239 
Basaran F, Ozbilgin H, Ozbilgin YD (2007) Effect of lordosis on the swimming performance of juvenile sea bass (Dicentrarchus labrax L.). Aquacult Res 38:870-876

Bassett L, Buchanan-Smith HM (2007) Effects of predictability on the welfare of captive animals. Appl Anim Behav Sci 102:223-245

Beamish FWH (1978) Swimming capacity. In: Hoar WS, Randall DJ (eds) Fish physiology. Academic Press, New York, pp 101-187

Beaumont MW, Butler PJ, Taylor EW, Mair JL, Mohammed MS (1996) Reduction in swimming performance of brown trout following copper exposure in soft acidic water. In: MacKinlay D, Nelson $\mathbf{J}$ (eds) International congress on the biology of fish, San Francisco, pp 127-132

Bégout-Anras ML, Lagardère JP (2004) Domestication et comportement chez les poisons téléostéens. INRA Prod Anim 17:211-215

Björnsson B (1993) Swimming speed and swimming metabolism of Atlantic cod (Gadus morhua) in relation to available food: a laboratory study. Can J Fish Aquat Sci 50:2542-2551

Boissy A, Manteuffel G, Jensen MB, Moe RO, Spruijt B, Keeling LJ, Winckler C, Forkman B, Dimitrov I, Langbein J, Bakken M, Veissier I, Aubert A (2007) Assessment of positive emotions in animals to improve their welfare. Physiol Behav 92:375-397

Boujard T, Labbé L, Aupérin B (2002) Feeding behaviour, energy expenditure and growth of rainbow trout in relation to stocking density and food accessibility. Aquacult Res 33:1233-1242

Braithwaite VA (2006) Cognitive ability in fish. Fish Physiol 24:1-37

Brännäs E, Alanärä A, Magnhagen C (2001) The social behaviour of fish. In: Keeling LJ, Gonyou HW (eds) Social behaviour of farm animals. CABI Publishing, Wallingford, pp 275-303

Bratland S, Stien LH, Braithwaite V, Juell J-E, Folkedal O, Nilsson J, Oppedal F, Fosseidengen JE, Kristiansen TS (2010) From fear to anticipation. Using aversive light stimuli to train reward conditioning in Atlantic salmon (Salmo salar L.). Aquacult Int 18:991-1001

Broom DM (1998) Welfare, stress, and the evolution of feelings. In: Moller AP, Milinski M, Slater PJB (eds) Advances in the study of behavior. Academic Press, San Diego, pp 371-403

Brydges NM, Boulcott P, Ellis T, Braithwaite VA (2009) Quantifying stress responses induced by different handling methods in three species of fish. Appl Anim Behav Sci 116:295-301

Burleson ML, Milsom WK (2003) Comparative aspects of $\mathrm{O}_{2}$ chemoreception: anatomy, physiology, and environmental adaptations. In: Lahiri S, Semenza GL, Prabhakar NR (eds) Oxygen sensing: responses and adaptation to hypoxia. Marcel Dekker, New York, pp 685-707

Byrne P, Ferguson HW, Lumsden JS, Ostland VE (1991) Blood-chemistry of bacterial gill disease in brook trout Salvelinus fontinalis. Dis Aquat Org 10:1-6

Cabanac M, Cabanac AJ, Parent A (2009) The emergence of consciousness in phylogeny. Behav Brain Res 198: 267-272
Cañon Jones HA, Hansen L, Noble C, Damsgård B, Broom DM, Pearce GP (2010) Social network analysis of behavioural interactions influencing fin damage development in Atlantic salmon (Salmo salar) during feedrestriction. Appl Anim Behav Sci 127:139-151

Carbonara P (2009) Un approccio metodologico integrato fra telemetria fisiologica e biomarker per la valutazione del benessere animale nella spigola (Dicentrarchus labrax L.). PhD dissertation, University of Siena, $165 \mathrm{pp}$

Carbonara P, Scolamacchia M, Spedicato MT, McKinley RS, Lembo G (2008) Muscle activity as a potential indicator of welfare in farmed European sea bass: results from an electromyographic (EMG) telemetry study. IFOAM conference on organic aquaculture, Cattolica, Italy, ICEA, pp 20-24

Carlstead K (1986) Predictability of feeding: its effect on agonistic behaviour and growth in grower pigs. Appl Anim Behav Sci 16:25-38

Carlstead K, Shepherdson D (2000) Alleviating stress in zoo animals. In: Moberg GP, Mench JA (eds) The biology of animal stress, basic principles and implications for animal welfare. University of Chicago Press, Chicago

Chandroo KP, Duncan IJH, Moccia RD (2004a) Can fish suffer?: perspectives on sentience, pain, fear and stress. Appl Anim Behav Sci 86:225-250

Chandroo KP, Yue S, Moccia RD (2004b) An evaluation of current perspectives on consciousness and pain in fishes. Fish Fish 5:281-295

Chandroo KP, Cooke SJ, Mckinley RS, Moccia RD (2005) Use of electromyogram telemetry to assess the behavioural and energetic responses of rainbow trout, Oncorhyncus mykiss (Walbaum) to transportation stress. Aquacult Res 36:1226-1238

Chen W-M, Purser GJ (2001) The effect of feeding regime on growth, locomotor activity pattern and the development of food anticipatory activity in greenback flounder. J Fish Biol 58:177-187

Conte FS (2004) Stress and the welfare of cultured fish. Appl Anim Behav Sci 86:205-223

Cooke SJ, Chandroo KP, Beddow TA, Moccia RD, McKinley RS (2000) Swimming activity and energetic expenditure of captive rainbow trout Oncorhynchus mykiss (Walbaum), estimated by electromyogram telemetry. Aquacult Res 31:495-506

Couillard CM, Courtenay SC, MacDonald RW (2008) Chemical-environment interactions affecting the risk of impacts on aquatic organisms: a review with a Canadian perspective-interactions affecting vulnerability. Environ Rev 16:19-44

Crocker CE, Cech JJ (1997) Effects of environmental hypoxia on oxygen consumption rate and swimming activity in juvenile white sturgeon, Acipenser transmontanus, in relation to temperature and life intervals. Environ Biol Fish 50:383-389

Cronin GM, Wiepkema PR, van Ree JM (1986) Andorphins implicated in stereotypies of tethered sows. Experientia 42:198-199

Damsgård B (2008) Husbandry techniques and fish quality. In: Lie $\varnothing$ (ed) Improved farmed fish and quality. Woodhead Publisher, Cambridge, pp 494-516 
Damsgård B, Dill LM (1998) Risk-taking behavior in weightcompensating coho salmon, Oncorhynchus kisutch. Behav Ecol 9:26-32

Danchin E, Giraldeau L, Cézilly F (2008) Behavioural ecology. Oxford University Press, Oxford

Dawkins MS (1990) From an animal's point of view: motivation, fitness, and animal welfare. Behav Brain Sci 13:1-61

Dawkins MS (1998) Evolution and animal welfare. Q Rev Biol 73:305-328

Dawkins MS (2004) Using behaviour to assess animal welfare. Anim Welfare 13:S3-S7

Day N, Butler PJ (1996) Environmental acidity and white muscle recruitment during swimming in the brown trout (Salmo trutta). J Exp Biol 199:1947-1959

Dempster T, Korsøen Ø, Oppedal F, Folkedal O, Juell JE (2009) Submergence of Atlantic salmon (Salmo salar) in sea-cages: a potential short-term solution to poor surface conditions. Aquaculture 288:254-263

Denight ML, Ward JA (1982) Relationship of chin spot size to dominance in the black-chinned mouthbrooding cichlid fish (Sarotherodon melanotheron). Anim Behav 30:1099-1104

Désiré L, Boissy A, Veissier I (2002) Emotions in farm animals: a new approach to animal welfare in applied ethology. Behav Process 60:165-180

Dill LM (1983) Adaptive flexibility in the foraging behavior of fishes (coho salmon Oncorhynchus kisutch). Can J Fish Aquat Sci 40:398-408

Domenici PD, Blake RW (1997) The kinematics and performance of fish fast-start swimming. J Exp Biol 200: $1165-1178$

Dugatkin LA (2004) Principles of animal behavior, 1st edn. W.W. Norton Publishing, New York

Duncan IJH (2005) Science-based assessment of animal welfare: farm animals. Rev Sci Tech Off Int Epiz 24:483-492

Duncan IJH, Dawkins MS (1983) The problem of assessing 'well-being' and 'suffering' in farm animals. In: Smidt D (ed) Indicators relevant to farm animal welfare. Martinus Nijhoff, The Hague, pp 13-24

Eclancher B, Dejours P (1975) Contrôle de la respiration chez les poisons téléostéens: existence de chémorécepteurs physiologiquement analogues aux chémorécepteurs des vertébrés supérieurs. C R Acad Sci 280D:451-453

Ejike C, Schreck CB (1980) Stress and social hierarchy rank in coho salmon. Trans Am Fish Soc 109:423-426

Ellis T, North B, Scott AP, Bromage NR, Porter M, Gadd D (2002) The relationships between stocking density and welfare in farmed rainbow trout. J Fish Biol 61:493-531

Ernst B, Hoeger SJ, O'Brien E, Dietrich DR (2007) Physiological stress and pathology in European whitefish (Coregonus lavaretus) induced by subchronic exposure to environmentally relevant densities of Planktothrix rubescens. Aquat Toxicol 82:15-26

Espmark AM, Baeverfjord G (2009) Effects of hyperoxia on behavioural and physiological variables in farmed Atlantic salmon (Salmo salar) parr. Aquacult Int 17:341-353

Farrell AP, Gamper K, Birthwell IK (1998) Prolonged swimming, recovery and repeat swimming performance of mature sockeye salmon Onchorhyncus nerka exposed to moderate hypoxia and pentachlorophenol. J Exp Biol 201:2183-2193

FASTFISH (2009) On farm assessment of stress level in fish. Final report. Unpublished report. http://fastfish.imr.no/_ data/page/7764/FASTFISH_Publishable_Final_Activity_ Report_draf_1.pdf

Fernö A, Huse I, Juell J-E, Bjordal Å (1995) Vertical distribution of Atlantic salmon (Salmo salar L.) in net pens: trade-off between surface light avoidance and food attraction. Aquaculture 132:285-296

Fernö A, Huse G, Jakobsen PJ, Kristiansen TS (2006) The role of fish learning skills in fisheries and aquaculture. In: Brown C, Laland K, Krause J (eds) Fish cognition and behaviour. Blackwell Publishing, Oxford, pp 119-138

Folkedal O (2010) Anticipatory behaviour as indicator for stress and welfare in farmed Atlantic salmon at different life stages. $\mathrm{PhD}$ thesis, University of Bergen, Norway

Føre M, Dempster T, Alfredsen JA, Johansen V, Johansson D (2009) Modelling of Atlantic salmon (Salmo salar L.) behaviour in sea-cages: a Lagrangian approach. Aquaculture 288:196-204

Fox HE, White SA, Kao MHF, Fernald RD (1997) Stress and dominance in a social fish. J Neurosci 17:6463-6469

Fry FEJ (1971) The effect of environmental factors on the physiology of fish. In: Hoar WS, Randall DJ (eds) Fish physiology, vol VI. New York Academy Press, New York, pp 1-99

Galhardo L (2010) Teleost welfare: behavioural, cognitive and physiological aspects in Oreochromis mossambicus. $\mathrm{PhD}$ thesis, University of Porto, $215 \mathrm{pp}$

Galhardo L, Correia J, Oliveira RF (2008) The effect of substrate availability on behavioural and physiological indicators of welfare in the African cichlid (Oreochromis mossambicus). Anim Welfare 17:239-254

Galhardo L, Almeida O, Oliveira RF (2009) Preference for the presence of substrate in male cichlid fish: effects of social dominance and context. Appl Anim Behav Sci 120:224-230

Galhardo L, Almeida O, Oliveira RF (2011a) Measuring motivation in a cichlid fish: an adaptation of the push-door paradigm. Appl Anim Behav Sci 130:60-70

Galhardo L, Almeida O, Oliveira RF (2011b) The role of predictability in the stress response of a cichlid fish. Physiol Behav 102:367-372

Grant JWA (1997) Territoriality. In: Godin J-GJ (ed) Behavioural ecology of teleost fishes. Oxford University Press, Oxford, pp 81-103

Greiveldinger L, Veissier I, Boissy A (2007) Emotional experience in sheep: predictability of a sudden event lowers subsequent emotional response. Physiol Behav 92:675-683

Greiveldinger L, Veissier I, Boissy A (2009) Behavioural and physiological responses of lambs to controllable vs. uncontrollable aversive events. Psychoneuroendocrinology $34: 805-814$

Guile MN (1987) Differential gastric ulceration in rats receiving shocks on either fixed-time or variable-time schedules. Behav Neurosci 101:139-140

Hakoyama H, Iguchi K (1997) Why is competition more intense if food is supplied more slowly? Behav Ecol Sociobiol 40:159-168 
Hansen LA, Dale T, Damsgård B, Uglem I, Aas K, Bjørn PA (2008) Escape-related behaviour of Atlantic cod, Gadus morhua L., in a simulated farm situation. Aquacult Res 40:26-34

Hasler CT, Suski CD, Hanson KC, Cooke SJ, Philipp DP, Tufts BL (2009) Effect of water temperature on laboratory swimming performance and natural activity levels of adult largemouth bass. Can J Zool 87:589-596

Heinrichs SC, Koob GF (2004) Corticotropin-releasing factor in brain: a role in activation, arousal, and affect regulation. J Pharmacol Exp Ther 311:427-440

Herbert NA, Steffensen JF (2005) The response of Atlantic cod, Gadus morhua, to progressive hypoxia: fish swimming speed and physiological stress. Mar Biol 147: 1403-1412

Hoare DJ, Krause J (2003) Social organisation, shoal structure and information transfer. Fish Fish 4:269-279

Höglund E, Weltzien FA, Schjolden J, Winberg S, Ursin H, Doving KB (2005) Avoidance behavior and brain monoamines in fish. Brain Res 1032:104-110

Hopkins WA, Snodgrass JW, Staub BP, Jackson BP, Congdon JD (2003) Altered swimming performance of a benthic fish (Erimyzon sucetta) exposed to contaminated sediments. Arch Environ Contam Toxicol 44:383-389

Huntingford FA, Turner AK (1987) Animal conflict. Chapman \& Hall, London, pp 64-71

Huntingford F, Adams C, Braithwait VA, Kadri S, Pottinger TG, Sandøe P, Turnbull JF (2006) Current issues in fish welfare. J Fish Biol 68:332-372

Huse I, Skiftesvik AB (1985) Qualitative and quantitative behaviour studies in starving and feeding turbot (Scophthalmus maximus L.) larvae. ICES 14:108-115

Ishida Y, Yoshikawa H, Kobayashi H (1996) Electrophysiological responses of three chemosensory systems in the carp to pesticides. Physiol Behav 60:633-638

Israeli-Weinstein D, Kimmel E (1998) Behavioral response of carp (Cyprinus carpio) to ammonia stress. Aquaculture 165:81-93

Jain KE, Birtwell IK, Farrell AP (1998) Repeat swimming performance of mature sockeye salmon following a brief recovery period: a proposed measure of fish health and water quality. Can J Zool 76:1488-1496

Jobling M (1983) Effect of feeding frequency on food intake and growth of Arctic charr, Salvelinus alpinus (L). J Fish Biol 23:177-185

Jobling M, Koskela J (1996) Interindividual variations in feeding and growth in rainbow trout during restricted feeding and in a subsequent period of compensatory growth. J Fish Biol 49:658-667

Johansson D, Ruohonen K, Kiessling A, Oppedal F, Stiansen J-E, Kelly M, Juell J-E (2006) Effect of environmental factors on swimming depth preferences of Atlantic salmon (Salmo salar L.) and temporal and spatial variations in oxygen levels in sea cages at a fjord site. Aquaculture 254:594-605

Johansson D, Juell J-E, Oppedal F, Stiansen J-E, Ruohonen K (2007) The influence of the pycnocline and cage resistance on current flow, oxygen flux and swimming behaviour of Atlantic salmon (Salmo salar L.) in production cages. Aquaculture 265:271-287
Jones DT, Moffitt CM (2004) Swimming endurance of bull trout, lake trout, Arctic char, and rainbow trout following challenge with Renibacterium salmoninarum. J Aquat Anim Health 16:10-22

Juell J-E (1995) The behaviour of Atlantic salmon in relation to efficient cage rearing. Rev Fish Biol Fish 5:320-335

Juell J-E, Fosseidengen JE (2004) Use of artificial light to control swimming depth and fish density of Atlantic salmon (Salmo salar) in production cages. Aquaculture 233:269-282

Juell J-E, Fernö A, Furevik D, Huse I (1994) Influence of hunger level and food availability on the spatial distribution of Atlantic salmon, Salmo salar L., in sea cages. Aquacult Fish Manage 25:439-451

Karakatsouli N, Papoutsoglou SE, Manolessos G (2007) Combined effects of rearing density and tank colour on the growth and welfare of juvenile White Sea bream Diplodus sargus L. in a recirculating water system. Aquacult Res 38:1152-1160

Keeley ER (2000) An experimental analysis of territory size in juvenile steelhead trout. Anim Behav 59:477-490

Kittilsen S, Ellis T, Schjolden J, Braastad B, Øverli Ø (2009) Determining stress responsiveness in family groups of Atlantic salmon (Salmo salar) using non-invasive measures. Aquaculture 298:146-152

Kleszczyńska A, Vargas-Chacoff L, Gozdowska M, Kalamarz H, Martínez-Rodríguez G, Mancera JM, Kulczykowska E (2006) Arginine vasotocin, isotocin and melatonin responses following acclimation of gilthead sea bream (Sparus aurata) to different environmental salinities. Comp Biochem Physiol A 145:268-273

Kleszczyńska A, Skorkowski EF, Kulczykowska E (2008) Stocking density influences brain arginine vasotocin (AVT) and isotocin (IT) concentrations in the three-spined stickleback. In: Resource management. Natural, human and material resources for the sustainable development in aquaculture. European aquaculture society special publication no. 37, September 2008. Inland Fisheries Institute, Olsztyn, pp 321-322

Kolstad K, Grisdale-Helland B, Gjerde B (2004) Family differences in feed efficiency in Atlantic salmon (Salmo salar). Aquaculture 241:169-177

Koolhaas JM, Korte SM, De Boer SF, Van der Vegt BJ, Van Reenen CG, Hopster H, De Jong IC, Ruis MAW, Blokhuis HJ (1999) Coping styles in animals: current status in behavior and stress-physiology. Neurosci Biobehav Rev 23:925-935

Korsøen Ø, Dempster T, Fjelldal PG, Folkedal O, Kristiansen T, Oppedal F (2009) Long-term submergence of Atlantic salmon (Salmo salar L.) during winter affects behaviour, growth and condition. Aquaculture 296:373-381

Korte SM, Olivier B, Koolhaas JM (2007) A new animal welfare concept based on allostasis. Physiol Behav 92:422-428

Kristiansen TS, Fernö A (2007) Individual behaviour and growth of halibut (Hippoglossus hippoglossus L.) fed sinking and floating feed: evidence of different coping styles. Appl Anim Behav Sci 104:236-250

Kristiansen TS, Fernö A, Holm JC, Privitera L, Bakke S, Fosseidengen JE (2004) Swimming behaviour as an indicator of low growth rate and impaired welfare in 
Atlantic halibut (Hippoglossus hippoglossus L.) reared at three stocking densities. Aquaculture 230:137-151

Kucukbay Z, Yazlak H, Sahin N, Tuzcun M, Cakmak MN, Gurdogan F, Juturu V, Sahin K (2006) Zinc picolinate supplementation decreases oxidative stress in rainbow trout (Oncorhynchus mykiss). Aquaculture 257:465-469

Kulczykowska E, Gozdowska M, Kalamarz H, Kleszczyńska A, Nietrzeba M, Martinez-Rodriguez G, Mancera JM (2009) Hypothalamic arginine vasotocin and isotocin are involved in stress response in fish. Comp Biochem Physiol A 154:S26

Lembo G, Carbonara P, Scolamacchia M, Spedicato MT, McKinley RS (2007) Use of muscle activity indices as a relative measure of well-being in cultured sea bass Dicentrarchus labrax (Linnaeus, 1758). Hydrobiologia 582:271-280

Lembo G, Carbonara P, Scolamacchia M, Spedicato MT, Bjørnsen JE, Holand B, McKinley RS (2008) Introduction of a new physiological sensor: an acoustic EMG transmitter. Fish Manage Ecol 15:333-338

MacKenzie S, Ribas L, Pilarczyk M, Capdevila DM, Kadri S, Huntingford FA (2009) Screening for coping style increases the power of gene expression studies. PLoS One 4:e5314

Mancera JM, Vargas-Chacoff L, García-López A, Kleszczyńska A, Kalamarz H, Martínez-Rodríguez G, Kulczykowska E (2008) High density and food-deprivation affect arginine vasotocin, isotocin and melatonin in gilthead sea bream (Sparus auratus). Comp Biochem Physiol A 149:92-97

Martins CIM, Aanyu M, Schrama JW, Verreth JAJ (2005) Size distribution in African catfish (Clarias gariepinus) affects feeding behaviour but not growth. Aquaculture 250:300-307

Martins CIM, Schrama JW, Verreth JAJ (2006a) The relationship between feed efficiency and stress response in African catfish Clarias gariepinus. Aquaculture 256: $588-595$

Martins CIM, Schrama JW, Verreth JAJ (2006b) The effect of grading on the welfare of African catfish. Appl Anim Behav Sci 97:323-334

Martins CIM, Hillen B, Schrama JW, Verreth JAJ (2008) A brief note on the relationship between residual feed intake and aggression behaviour in juveniles of African catfish Clarias gariepinus. Appl Anim Behav Sci 111:408-413

Martins CIM, Ochola DM, Ende S, Eding E, Verreth JAJ (2009) Is growth retardation present in Nile tilapia Oreochromis niloticus cultured in low water exchange recirculating aquaculture systems? Aquaculture 298:43-50

Mason GJ (1991) Stereotypies: a critical review. Anim Behav 41:1015-1037

Mason G, Rushen J (2006) Stereotypies in captive animals: fundamentals and implications for welfare, 2 nd edn. CAB International, Wallingford

Massabuau JC (2001) From a low blood- to low tissue-oxygenation strategy, an evolutionary theory. Respir Physiol 128:249-262

Massabuau JC (2003) Primitive, and protective, our cellular oxygenation status? Mech Ageing Dev 124:857-863

McFarlane WJ, Cubitt KF, Williams H, Rowsell D, Moccia R, Gosine R, McKinley RS (2004) Can feeding status and stress level be assessed by analyzing pattern of muscle activity in free swimming rainbow trout (Oncorhynchus mykiss Walbaum)? Aquaculture 239:467-484

Metcalfe NB, Huntingford FA, Thorpe JE (1987) The influence of predation risk on the feeding motivation and foraging strategy of juvenile Atlantic salmon. Anim Behav 35:901-911

Moreira PSA, Pulman KGT, Pottinger TG (2004) Extinction of a conditioned response in rainbow trout selected for high or low responsiveness to stress. Hormones Behav 46:450-457

Morgan KN, Tromborg CT (2007) Sources of stress in captivity. Appl Anim Behav Sci 102:262-302

Muir JL, Pfister HP (1986) Corticosterone and prolactin responses to predictable and unpredictable novely stress in rats. Physiol Behav 37:285-288

Neely WB (1979) Estimating rate constants for the uptake and clearance of chemicals by fish. Environ Sci Technol 13:1506-1510

Noble C, Mizusawa K, Suzuki K, Tabata M (2007a) The effect of differing self-feeding regimes on the growth, behaviour and fin damage of rainbow trout held in groups. Aquaculture 264:214-222

Noble C, Kadri S, Mitchell DF, Huntingford FA (2007b) Influence of feeding regime on intraspecific competition, fin damage and growth in $1+$ Atlantic salmon parr (Salmo salar L.) held in freshwater production cages. Aquacult Res 38:1137-1143

Noble C, Kadri S, Mitchell DF, Huntingford FA (2007c) The effect of feed regime on the growth and behaviour of $1+$ Atlantic salmon post-smolts (Salmo salar L.) in semicommercial sea cages. Aquacult Res 38:1686-1691

Noble C, Kadri S, Mitchell DF, Huntingford FA (2008) Growth, production and fin damage in cage-held $0+$ Atlantic salmon pre-smolts (Salmo salar L.) fed either (a) on-demand, or (b) to a fixed satiation-restriction regime: data from a commercial farm. Aquaculture 275:163-168

O'Connor KI, Metcalfe NB, Taylor AC (1999) Does darkening signal submission in territorial contests between juvenile Atlantic salmon, Salmo salar? Anim Behav 58:1269-1276

Oppedal F, Juell J-E, Johansson D (2007) Thermo-and photoregulatory swimming behaviour of caged Atlantic salmon: implications for photoperiod management and fish welfare. Aquaculture 265:70-81

Oppedal F, Dempster T, Stien LH (2011) Environmental drivers of Atlantic salmon behaviour in sea-cages: a review. Aquaculture 311:1-18

Orsini C, Ventura R, Lucchese F, Puglisi-Allegra S, Cabib S (2002) Predictable stress promotes place preference and low mesoaccumbens dopamine response. Physiol Behav 75:135-141

Osborne WA, Muntz E (1906) The action of carbon di-oxide on the respiration of the gold fish. Biochem J 1:377-382

Øverli Ø, Winberg S, Damsgård B, Jobling M (1998) Food intake and spontaneous swimming activity in Arctic charr (Salvelinus alpinus L.): role of brain serotonergic activity and social interaction. Can J Zool 76:1366-1370

Øverli Ø, Olsen RE, Løvik F, Ring E (1999) Dominance hierarchies in Arctic charr, Salvelinus alpinus L.: differential cortisol profiles of dominant and subordinate individuals after handling stress. Aquacult Res 30:259-264 
Øverli Ø, Sørensen C, Kiessling A, Pottinger TG, Gjøen HM (2006a) Selection for improved stress tolerance in rainbow trout (Oncorhynchus mykiss) leads to reduced feed waste. Aquaculture 261:776-781

Øverli Ø, Sørensen C, Nilsson G (2006b) Behavioral indicators of stress-coping style in rainbow trout: do males and females react differently to novelty? Physiol Behav 87:506-512

Øverli Ø, Sørensen C, Pulman KGT, Pottinger TG, Korzan W, Summers CH, Nilsson GE (2007) Evolutionary background for stress-coping styles: relationships between physiological, behavioral, and cognitive traits in nonmammalian vertebrates. Neurosci Biobehav Rev 31: 396-412

Pane EF, Haque A, Wood CA (2004) Mechanistic analysis of acute, $\mathrm{Ni}$-induced respiratory toxicity in the rainbow trout (Oncorhynchus mykiss): an exclusively branchial phenomenon. Aquat Toxicol 69:11-24

Parrish JK, Viscido SV, Grunbaum D (2002) Self-organized fish schools: an examination of emergent properties. Biol Bull 202:296-305

Pierron F, Baudrimont M, Gonzalez P, Bourdineaud JP, Elie P, Massabuau JC (2007) Common pattern of gene expression in response to hypoxia or cadmium in the gills of the European glass eel (Anguilla anguilla). Environ Sci Technol 41:3005-3011

Pitcher TJ, Parrish JK (1993) Functions of shoaling behaviour in teleosts. In: Pitcher TJ (ed) Behaviour of teleost fish. Chapman \& Hall, London, pp 363-439

Pitcher TJ, Magurran AE, Winfield IJ (1982) Fish in larger shoals find food faster. Behav Ecol Sociobiol 10:149-151

Plaut I (2001) Critical swimming performance: its ecological relevance. Comp Biochem Physiol 131A:41-50

Poli BM, Parisi G, Scappini F, Zampacavallo G (2005) Fish welfare and quality as affected by pre-slaughter and slaughter management. Aquacult Int 13:29-49

Portavella M, Vargas JP (2005) Emotional and spatial learning in goldfish is dependent on different telencephalic pallial systems. Eur J Neurosci 21:2800-2806

Pottinger TG (2006) Context dependent differences in growth of two rainbow trout (Oncorhynchus mykiss) lines selected for divergent stress responsiveness. Aquaculture 256:140-147

Pottinger TG, Carrick TR (2001a) ACTH does not mediate divergent stress responsiveness in rainbow trout. Comp Biochem Physiol A 129:399-404

Pottinger TG, Carrick TR (2001b) Stress responsiveness affects dominant-subordinate relationships in rainbow trout. Horm Behav 40:419-427

Prior H (2002) Effects of predictable and unpredictable intermittent noise on spatial learning in rats. Behav Brain Res 133:117-124

Priyadarshana T, Asaeda T, Manatunge J (2006) Hungerinduced foraging behavior of two cyprinid fish: Pseudorasbora parva and Rasbora daniconius. Hydrobiology 568:341-352

Randall DJ (1982) The control of respiration and circulation in fish during exercise and hypoxia. J Exp Biol 100:275-288

Ritola O, Livimgstone DR, Peters LD, Lindstrom-Seppa P (2002) Antioxidant processes are affected in juvenile rainbow trout (Oncorhynchus mykiss) exposed to ozone and oxygen surpersaturated water. Aquaculture 210:1-19
Rodriguez F, Broglio C, Duran E, Gomez A, Salas C (2006) Neural mechanisms of learning in teleost fish. In: Brown C, Laland K, Krause J (eds) Fish cognition and behaviour. Blackwell Publishing, Oxford, pp 243-277

Romey WL (1996) Individual differences make a difference in the trajectories of simulated schools. Ecol Model 92: $65-77$

Rose JD (2002) The neurobehavioral nature of fishes and the question of awareness and pain. Rev Fish Sci 10:1-38

Rose JD (2007) Anthropomorphism and 'mental welfare' of fishes. Dis Aquat Organ 75:139-154

Ross RM, Watten BJ, Krise WF, DiLauro MN (1995) Influence of tank design and hydraulic loading on the behavior, growth, and metabolism of rainbow trout (Oncorhynchus mykiss). Aquacult Eng 14:29-47

Rousing T, Bonde M, Sørensen JT (2001) Aggregating welfare indicators into an operational welfare assessment system: a bottom up approach. Acta Agric Scand Anim Sci Suppl 30:53-58

Rubio VC, Sánchez E, Cerdá-Reverter JM (2010) Compensatory feeding in the sea bass after fasting and physical stress. Aquaculture 298:332-337

Ruiz-Gomez ML, Kittilsen S, Höglund E, Huntingford FA, Sørensen C, Pottinger TG, Bakken M, Winberg S, Korzan WJ, Øverli Ø (2008) Behavioral plasticity in rainbow trout (Oncorhynchus mykiss) with divergent coping styles: when doves become hawks. Hormones Behav 54:534-538

Ryer CH, Olla BL (1991) Information-transfer and the facilitation and inhibition of feeding in a schooling fish. Environ Biol Fish 30:317-323

Ryer CH, Olla BL (1992) Social mechanisms facilitating exploitation of spatially variable ephemeral food patches in a pelagic marine fish. Anim Behav 44:69-74

Salek SJ, Sullivan CV, Godwin J (2002) Arginine vasotocin effects on courtship behavior in male white perch (Morone americana). Behav Brain Res 133:177-183

Sánchez JA, López-Olmeda JF, Blanco-Vives B, SánchezVázquez FJ (2009) Effects of feeding schedule on locomotor activity rhythms and stress response in sea bream. Physiol Behav 98:125-129

Santos GA, Schrama JW, Mamauag REP, Rombout JHWM, Verreth JAJ (2010) Chronic stress impairs performance, energy metabolism and welfare indicators in European seabass (Dicentrarchus labrax): the combined effects of fish crowding and water quality deterioration. Aquaculture 299:73-80

Schreck CB (1981) Stress and compensation in teleostean fishes: response to social and physical factors. In: Pickering AD (ed) Stress and fish. Academic Press, New York, pp 294-321

Schulze Westerath H, Laister S, Winckler C, Knierim U (2009) Exploration as an indicator of good welfare in beef bulls: an attempt to develop a test for on-farm assessment. Appl Anim Behav Sci 116:126-133

Schurmann H, Steffensen JF (1994) Spontaneous swimming activity of Atlantic cod Gadus morhua exposed to graded hypoxia at three temperatures. J Exp Biol 197:129-142

Scolamacchia M (2009) Eco-physiological indicators and evaluation of stress factors in European sea bass Dicentrarchus labrax (Linnaeus, 1758). $\mathrm{PhD}$ thesis, University of Bari, Bari, 162 pp 
Scott AP, Ellis T (2007) Measurement of fish steroids in water-a review. Gen Comp Endocr 153:392-400

Scott GR, Sloman KA (2004) The effects of environmental pollutants on complex fish behaviour: integrating behavioural and physiological indicators of toxicity. Aquat Toxicol 68:369-392

Scott AP, Hirschenhauser K, Bender N, Oliveira R, Earley RL, Sebire M, Ellis T, Pavlidis M, Hubbard PC, Huertas M, Canario A (2008) Non-invasive measurement of steroids in fish-holding water: important considerations when applying the procedure to behaviour studies. Behaviour 145(suppl SI):1307-1328

Semsar K, Kandel FL, Godwin J (2001) Manipulation of the AVT system shift social status and related courtship and aggressive behavior in the bluehead wrasse. Horm Behav 40:21-31

Shingles A, McKenzie DJ, Taylor EW, Moretti A, Butler PJ, Ceradini S (2001) Effects of sublethal ammonia exposure on swimming performance in rainbow trout (Oncorhynchus mykiss). J Exp Biol 204:2691-2698

Smith CJ, Shaw SBJ, Handy RD (2007) Toxicity of single walled carbon nanotubes to rainbow trout, (Oncorhynchus mykiss): respiratory toxicity, organ pathologies, and other physiological effects. Aquat Toxicol 82:94-109

Sneddon L (2007) Assessing pain perception in fish from physiology to behaviour. Comp Biochem Physiol A 146:S78

Sneddon LU, Braithwaite VA, Gentle MJ (2003) Novel object test: examining nociception and fear in the rainbow trout. J Pain 4:431-440

Sordillo LM, Aitken SL (2009) Impact of oxidative stress on the health and immune function of dairy cattle. Vet Immunol Immunopathol 128:104-109

Sørum U, Damsgård B (2004) Effects of anaesthetisation and vaccination on feed intake and growth in Atlantic salmon (Salmo salar L.). Aquaculture 232:333-341

Spruijt BM, Bos R, Pijlman FTA (2001) A Concept of welfare based on reward evaluating mechanisms in the brain: anticipatory behaviour as an indicator for the state of reward systems. Appl Anim Behav Sci 72:145-171

Stien LH, Bratland S, Austevoll I, Oppedal F, Kristiansen TS (2007) A video analysis procedure for assessing vertical fish distribution in aquaculture tanks. Aquacult Eng 37: 115-124

Suzuki K, Mizusawa K, Noble C, Tabata M (2008) The growth, feed conversion ratio and fin damage of rainbow trout Oncorhynchus mykiss under self-feeding and handfeeding regimes. Fish Sci 74:941-943

Swanson C, Baxa DV, Young PS, Cech JJ, Hedrick RP (2002) Reduced swimming performance in delta smelt infected with Mycobacterium spp. J Fish Biol 61: 1012-1020

Symons PEK (1968) Increase in aggression and the strength of the social hierarchy among juvenile Atlantic salmon deprived of food. J Fish Res Board Can 25:2387-2401

Tang M, Boisclair D (1995) Relationship between respiration rate of juvenile brook trout (Salvelinus fontinalis), water temperature, and swimming characteristics. Can J Fish Aquat Sci 52:2138-2145

Terova G, Gornati R, Rimoldi S, Bernardini G, Saroglia M (2005) Quantification of a glucocorticoid receptor in sea bass (Dicentrarchus labrax L.) reared at high stocking density. Gene 357:144-151

Thompson RR, Watson JC (2004) Peptide effects on social behavior: effects of vasotocin and isotocin on social approach behavior in male goldfish (Carassius auratus). Bahav Neurosci 118:620-626

Tierney KB, Farrell AP (2004) The relationships between fish health, metabolic rate, swimming performance and recovery in return-run sockeye salmon, Oncorhynchus nerka (Walbaum). J Fish Dis 27:663-671

Trenzado CE, Morales AE, de la Higuera M (2006) Physiological effects of crowding in rainbow trout, Oncorhynchus mykiss, selected for low and high stress responsiveness. Aquaculture 258:583-593

Turnbull JF, Kadri S (2007) Safeguarding the many guises of farmed fish welfare. Dis Aquat Org 75:173-182

van de Nieuwegiessen PG, Boerlage AS, Verreth JAJ, Schrama JW (2008) Assessing the effects of a chronic stressor, stocking density, on welfare indicators of juvenile African catfish, Clarias gariepinus Burchell. Appl Anim Behav Sci 115:233-243

van de Nieuwegiessen PG, Olwo J, Khong S, Verreth JAJ, Schrama JW (2009) Effects of age and stocking density on the welfare of African catfish, Clarias gariepinus Burchell. Aquaculture 288:69-75

Veissier I, Boissy A, Désiré L, Greiveldinger L (2009) Animals' emotions: studies in sheep using appraisal theories. Anim Welfare 18:347-354

von Borell E (1995) Neuroendocrine integration of stress and significance of stress for the performance of farm animals. Appl Anim Behav Sci 44:219-227

Wagner GN, McKinley RS, Bjørn PA, Finstad B (2003) Physiological impact of sea lice on swimming performance of Atlantic salmon. J Fish Biol 62:1000-1009

Wagner GN, Balfry SK, Higgs DA, Lall SP, Farrell AP (2004) Dietary fatty acids composition affects the repeat swimming performance of Atlantic Salmon in seawater. Comp Biochem Physiol 137A:567-576

Warren JW (1982) Diseases of hatchery fish. US fish \& wildlife service, region 3 , twin cities. Minnesota stock no. 024-010-00-622-6, US Government Printing Office, Washington, DC, $91 \mathrm{pp}$

Wemelsfelder F (1993) The concept of boredom and its relationship to stereotyped behavior. In: Lawrence AB, Rushen J (eds) Stereotypic behavior: fundamentals and applications to animal welfare. CAB International, Wallingford

Wendelaar Bonga SE (1997) The stress response in fish. Physiol Rev 77:591-625

White AJ, Schreer JF, Cooke SJ (2008) Behavorial and physiological responses of the congeneric largemouth (Micropterus salmoides) and smallmouth bass (M. dolomieu) to various exercise and air exposure durations. Fish Res 89:9-16

Wiepkema PR (1987) Behavioural aspects of stress. In: Wiepkema PR, Van Adrichem PWM (eds) Biology of stress in farm animals: an integrative approach. Martinus Nijhoff Publishers, Dordrecht, pp 113-133

Winberg S, Nilsson GE (1993a) Roles of brain monoamine neurotransmitters in agonistic behaviour and stress reactions, with particular reference to fish. Comp Biochem Physiol 106:597-614 
Winberg S, Nilsson GE (1993b) Time course of changes in brain serotonergic activity and brain tryptophan levels in dominant and subordinate juvenile Arctic charr. J Exp Biol 179:181-195

Wolter C, Arlinghaus R (2004) Burst and critical swimming speed of fish and their ecological relevance in waterways. In: Leibniz-Institut für Gewässerökologie und Binnenfischerei (IGB) (ed) Annual report 2003, pp 77-93

Würbel H (2009) The state of ethological approaches to the assessment of animal suffering and welfare. Appl Anim Behav Sci 118:105-107
Würbel H, Stauffacher M (1997) Age and weight at weaning affect corticosterone level and development of stereotypies in ICR-mice. Anim Behav 53:891-900

Xu J, Liu Y, Cui S, Miao X (2006) Behavioral responses of tilapia (Oreochromis niloticus) to acute fluctuations in dissolved oxygen levels as monitored by computer vision. Aquacult Eng 35:207-217

Yue S, Duncan IJH, Moccia RD (2008) Investigating fear in rainbow trout (Oncorhynchus mykiss) using the conditioned-suppression paradigm. J Appl Anim Welfare Sci 11:14-27 